\title{
Governance Indicators and Responsiveness to Population Decline: School Closures in Practice and Discourse in Saxony-Anhalt
}

\author{
Walter Bartl, Reinhold Sackmann
}

\begin{abstract}
The subject of this analysis is the practice of school closures, since it constitutes a key response to demographic decline and is usually hotly disputed in regional discussions on demographic change. Our research is guided by two questions: How do political and administrative responses to demographic decline emerge? How is the practice of school closure publicly portrayed and discussed in the newspapers? We assume that in democratic welfare regimes, the spatial allocation of school infrastructures is mediated by the use of key administrative indicators allowing the calculation and public deliberation of questions related to education infrastructure policy. However, in transformation societies, a democratic political culture of "governing by numbers" only develops as a result of collective learning processes in which the participants acquire what we refer to as "democratic numeracy". In the stratified German school system, social prestige is conferred unequally among the different school types, with the grammar school (Gymnasium) being the most prestigious school type. It is therefore likely that the elements of the school system are not affected equally by policy responses to demographic decline and public attention, which results in spatial inequalities. Empirically, the article follows a mixed-methods approach, whilst emphasising a quantitative and qualitative content analysis of school closures in the regional press of Saxony-Anhalt from 1990 to 2014. The results show that, in the transformation process, the relevance of indicator-based governance of the school infrastructure increases both in practice and in discourse. However, as the participants gain in democratic numeracy, the use of numbers becomes politicised. With respect to the pattern of school closures, grammar schools receive a disproportionately large share of public attention. This has a positive effect on their survival chances and diminishes differences in spatial distances between grammar schools and integrated secondary schools.
\end{abstract}

Keywords: Demographic change - Governance - Quantification · School planning · Content analysis 


\section{Introduction}

Demographic change in the form of ageing and shrinking populations is seen as a mega trend of current and future social change. Nearly all nations are already ageing; a small number of them are also registering a decline in population size. Especially in a regional perspective, the latter trend is being observed in a rising number of European and Asian countries, and this has serious repercussions for the education system.

Knowledge within the social sciences concerning societies' response to a declining population is still controversial: Some demographers state that demographic change will be the main determinant of social developments (Birg 2001), whilst other social scientists tend to find demographic change irrelevant (Butterwegge/Klundt 2003). Both extreme positions are somewhat vague as to their theoretical concepts of the connection between demographic change and societal response, suggesting some kind of law-like determination on the one hand, as against a kind of social constructivism which gives discourse a central role, on the other.

We will be focusing on an empirical analysis to see how the two dimensions of demographic development and public discourse are interlinked. The subject of this analysis is the practice of school closures, since it constitutes a key response to demographic decline, and is usually hotly disputed in regional discussions on demographic change. A guiding question for the analysis is: How do political and administrative responses to demographic decline emerge? The second lead question is: How are practices of school closure publicly portrayed and discussed in newspapers? We therefore try to relate the structure of practice to the patterns of discourse.

As a theoretical starting point, we borrow an argument from recent discussions about the quantification of politics and apply it to the governance of school infrastructure in the context of demographic decline in Eastern Germany. First, we assume that, in democratic welfare regimes, the spatial allocation of school infrastructures is governed by key administrative indicators allowing the calculation and public deliberation of questions of spatial justice, pedagogical adequacy, and economic viability. The systematic use of numbers is important not only for administrative practice, but also for legitimating this practice in public discourse (Desrosières 2005; Rose 1991). By emphasising the political nature of school infrastructure governance, we diverge on the one hand from (economic) research, which assumes a general practice of economic calculation in the field of education policy without ever questioning the adequacy of this assumption. On the other hand, we also diverge from contributions of discourse analysis suggesting that the use of demographic projections in politics would preclude political deliberation and conflict (Barlösius 2007; cf. Messerschmidt 2014). Second, we assume that a democratic political culture of "governing by numbers" is not a fact, but might emerge historically as a contingent result of collective learning processes in which the participants acquire what we call "democratic numeracy" (cf. Cohen 1982; Rose 1991). The governance of school infrastructure in the (post-)transformation context of Eastern Germany is especially interesting in this respect because the states of the former Eastern Bloc differed significantly from the established Western democracies in their public use 
of statistics. Third, investigating school closures in the stratified German school system seems to be especially relevant for the spatial re-structuring of educational opportunities because social prestige is conferred unequally among the different school types, with the grammar school (Gymnasium, hosting the most advanced secondary school track) being the most prestigious school type (Tenorth 2008). Hence, it is likely that sections of the hierarchically-differentiated school system are not affected equally by policy responses to demographic decline and public attention.

The article begins by discussing the theoretical concepts used in our field of inquiry and elaborating our own approach. This is followed by a presentation of the data and methodology employed, emphasising a quantitative and qualitative content analysis of school closures in the regional press of Saxony-Anhalt from 1990 to 2014. The results in the fourth chapter focus on the process of school closures and the pattern of reporting on it.

\section{Education policy and education administration responding to demographic change}

\subsection{Demographic decline and school closures: Previous research}

One strand in social science literature analyses the effects of demographic decline on educational expenditure. An (implicit) criterion of this mainly economic literature is the proportional elasticity of education expenditure to accommodate pupil cohort sizes, which would indicate an efficient adaptation of supply capacities in line with "demand". Most studies registered that the adaptation of expenditure fell short of the corresponding decline in the number of pupils, both in size and velocity (Poterba 1997; Wolter 2009; Ratts $\varnothing / S \varnothing r e n s e n$ 2010). However, some studies on primary schools in Eastern Germany (Kempkes 2010) and school expenditure in Japan (Ohtake/Sano 2010) show that the infrastructure adapted with rather high elasticity. As these studies mainly apply secondary data analyses to administrative process data, it remains unclear whether the cost stickiness that has been observed is the result of unintended inertia or of politically-desirable investment in education.

An interdisciplinary discourse is concerned with the effects of population decline on school infrastructure, whereby the focus is on school closures, as these are often described as having detrimental effects on communities (e.g. Kearns et al. 2010; Egelund/Laustsen 2006; Autti/Hyry-Beihammer 2014; Barakat et al. 2011; Elshof et al. 2015), albeit this view is not universally held (Godinho 2012; Barakat 2014). School closures were rather common in industrialised countries in the second half of the $20^{\text {th }}$ century and the beginning of the $21^{\text {st }}$. This recently applied to Germany, especially to Eastern Germany (Weishaupt 2006). The causes of this development are diverse, and cannot be reduced to a demographic decline in the number of pupils alone. Also, a socially widespread pedagogical orientation which associates larger schools with a better quality of instruction is an important reason for this development (Kramer 1997; Meusburger 1998: 394-398; Frank 2011). Other causes are 
rising aspirations for higher education - which in stratified school systems eschew academically less demanding secondary schools (Helbig/Schmolke 2015) -, social segregation (Bondi 1987), the education standard attained by schools (Billger 2010), as well as the organisational capability of interest groups (Stinchcombe 1984; Post) Stambach 1999), and the (protest) strategies that they employ (Uba 2015; Larsson Taghizadeh 2015; Finnigan/Lavner 2012; Phipps 2000), which are also seen as influential factors for school closures. A relatively recent phenomenon is the closure of schools with a perceived poor performance (Ewen 1997; Elacqua et al. 2012; Engberg et al. 2012). Although the literature on school closure repeatedly stresses how controversial these decisions are, the political processes involved have so far been the object of only very limited case studies on individual school closures. In particular, the roles played by key administrative indicators and by public discourse in these processes have not been analysed in any systematic manner.

\subsection{Political responsiveness to demographic change}

In order to obtain a precise understanding of how the political system reacts to demographic change, it is useful to apply the concept of responsiveness. Taken literally, "response" means answer. In political sciences, responsiveness has two dimensions. Assuming democratic premises, it means that policy on the one hand takes up voters' wishes, and on the other hand explains decisions taken by answering respective questions in public discussions (Uppendahl 1981; Behnke 2009). In this respect, the mass media are important transmitters of adequate information, both in the process of policy formation as well as in the processes of democratic control (Sarcinelli 2012; Bes/ey/Burgess 2002; Soroka/Wlezien 2015). Similar arguments on the processes of policy formation and political control have been made for the use of statistics (Kelman 1987: 280-286; Prewitt 1987). Hence, both forms of communication, i.e. the mass media and statistics, are assigned an intermediary role in the constitution of political responsiveness. We take up this argument from both fields of knowledge, and in doing so assume that the mass media and statistics are not copies of a pre-existing reality, but that they constitute realities in their own right. $^{1}$

Based on such a two-dimensional concept of responsiveness, the present article investigates processes of policy formation and legitimation of political decisions that refer to demographic problems of school infrastructure. We define a demographic problem as a discrepancy of demographic conditions and social (in our context often legally codified) expectations that has to be settled (cf. Merton 1976: 7). But what do demographic problems in school infrastructure policy consist of, and how is demand for collective decisions produced?

1 There is more knowledge about the effects of the mass media than there is about the effects of statistics (Starr 1987: 52). 


\subsection{Administrative key indicators of school planning}

We will argue in this section that demographic problems related to school infrastructure are essentially defined via key administrative indicators, that is via quantifications of social reality which are crucial to collective decision-making and democratic control. These indicators constitute the subjects of political decisions and public debate (cf. Desrosières 2005: 360).

Modern welfare states secure the loyalty of their citizens by implementing programmes to include the population politically and economically (Bommes 1999). In a spatial dimension, these inclusive programmes have resulted in the establishment of technical and social infrastructures (Kaufmann 2012) such as education facilities. Schooling is (still) provided in many countries in a largely decommodified environment where market prices do not apply (Sackmann 2010a: 370). When school systems lack the signalling function of a market, key administrative indicators become decisive for adjusting school infrastructure capacities in line with the needs of the spatially distributed target populations and with legitimate decisions taken. In instrumental terms, quantitative indicators allow the administration to calculate building and personnel capacities, provided as services in kind. Calculations of such services relate units of production directly to units of consumption. Only in further steps of administrative practice are these calculations of services in kind translated into monetised values which can be used to (de)legitimate existing structures. As with the technical and legitimating functions of double entry bookkeeping in business (Carruthers/Espeland 1991), public administration indicators can be expected to form not only the object of educational governance, but also that of public discourse, thus (de)legitimating this administrative practice (cf. Desrosières 2005: 360).

The institutionalisation of school planning as an administrative script of world culture (Meyer/Ramirez 2012) from the 1950s onwards appears to be particularly relevant to the responsiveness of school infrastructure to demographic change. While the first instances of education planning can be traced back to the early $19^{\text {th }}$ century in Europe, the worldwide promotion of education planning by international organisations only took on systematic shape after the Second World War (Lynch) Tason 1984: 316). This does not preclude the possibility that the implementation of planning models very often falls short of the political targets they were meant to reach - because of a lack of data, poor technology, or a shortage of qualified personnel (Jones 1975: 75). ${ }^{2}$ It can be observed for Western Germany that, by the late 1960s, education planning was considered a legitimate process within public administration that was to be implemented as soon as possible on various state levels (cf. Frommberger 1974; Brixner 1972; Deutscher Bildungsrat 1973: 270-275). The political aim was to provide equal educational opportunities to different local populations.

2 Rather than looking at snapshot views of school planning, it is important to assess the direction of changes (cf. Anderson-Levitt 2003). 
We argue that the responsiveness of school planning to demographic change crucially rests on two types of administrative quantification: population indicators on the one hand, and indicators of organisational viability on the other. A common feature of professional reflections on education planning practice is the recommendation of population indicators in order to make quantitative projections of future enrolments (e.g. Jacoby 1959; Jones 1975; Rösner 2004). ${ }^{3}$ Hence, while not all planners will necessarily use population indicators in the same way, these professional recommendations do suggest that planners will nevertheless consider their use as a normatively legitimate practice within school planning. The systematic use of demographic projections shifts the time horizon of collective decision-making from short-term to long-term perspectives (cf. Keyfitz 1987). Apart from the estimation of future enrolments, school authorities are also concerned with schools' organisational viability. When we talk about organisational viability, we are referring to administrative criteria which define features considered to be necessary for the continued existence of a school. Frequently-used indicators of organisational viability are size thresholds of classes or schools (cf. Frank 2011). Similar to business insolvency regimes, indicators of organisational viability - such as school size - allow decisions to be taken as to which schools should no longer be permitted to exist. Formally-defined requirements of minimum school sizes act as "statistical rules" (Starr 1987: 55) reducing personal discretion and enhancing democratic control. While it could be argued that the tradition of codified law in continental Europe favours such formally-defined threshold indicators of organisational viability, it is interesting to note that this criterion is also used informally in English-speaking countries which share a tradition of case-law (e.g. Bondi 1989; Basu 2007). Organisational size indicators reduce complexity in terms of at least two dimensions: Firstly, they suggest clear-cut categorical thresholds, even though the scientific evidence on the effects of class size (Arnhold 2005; Hattie 2005) or school size (Ares Abalde 2014; Döring 1977 ) is mixed. Secondly, while the interdisciplinary studies in this field differentiate between various dimensions of effects - such as economic efficiency and the pedagogical effectiveness of learning conditions -, size thresholds in school administration seem to symbolise both economic and pedagogical professional values at the same time.

$\mathrm{H} 1$ : Our first hypothesis is therefore that demographically-induced problems of school infrastructure are not determined by demographic change "as such", but are constituted through the systematic use of administrative numbers indicating a discrepancy between demographic conditions and political or administrative expectations (problem constitution hypothesis).

Quantitatively-constituted demographic problems of school infrastructure not only inform political decision processes, but also objectify them in the public de-

3 We do not argue that the literature on school planning exclusively recommends population indicators to estimate future enrolments. On the contrary, many models are more complex, including school choice options, dropout rates, grade retention, etc. However, we are trying to clarify the responsiveness of school planning to demographic change. 
bate. Whereas some scholars argue that the communication of numbers is likely to evoke less dissent than the communication of words because their contingency is less obvious (Heintz 2007), competent users of key administrative indicators might well know or learn about the (hidden) contingencies involved in the production of these numbers, and contest them. Hence, when demographic problems are essentially constituted by numbers, this does not preclude critical (public) discourse in the way that some contributions might suggest (cf. Barlösius 2007). Pragmatist accounts of the use of statistics emphasise that numerically-constituted objects are always subject to critical examinations (Desrosières 2005: 375).

\subsection{Democratic numeracy: decision-makers and the public}

The systematic use of numbers in politics has intensified due to the rising complexity of an ever more connected World Society (Rottenburg/Merry 2015), and due to the diffusion of the New Public Management discourse (Kro// 2012). However, a precondition for political planning and democratic public control in the mode of administrative indicators is that both administrators and the electorate possess a minimum of numeric competence (numeracy) (Cohen 1982; Rose 1991). Numeracy is the "ability to count, keep records of these counts, and make rational calculations" (Emigh 2002: 253). According to Patricia Cohen's (1982) account of the development of numeracy in the United Kingdom, and in the United States, the spread of elementary education and the regular publication of official statistics were important factors in this process. Other historians have pointed out that the population's previous experiences with informal calculation methods, e.g. on pre-capitalist local markets, deserve more attention (Emigh 2002), an argument that highlights the rather more interactive than "top-down" nature of the formation of numeracy.

While the pioneering studies of numeracy treat this competence as a basic element of democratic political culture, it would certainly be misleading to universalise this feature as if it applied to every modern society (cf. Parsons 1964). On the one hand, the worldwide expansion of mass education (Meyer et al. 1992) would actually support such a generalisation. But on the other hand, the public use of statistics has always been associated with democratic regimes (Kelman 1987), while non-democratic regimes, such as those of the former Eastern Bloc, are said to be far more restrictive and manipulative with regard to the publication of quantitative information on their societies (Starr 1987: 13,38). Official statistics in the German Democratic Republic for example were deliberately manipulated before publication, usually in order to align them to political targets (Lippe 1999, 2002). Furthermore, school planning was a centralised administrative procedure (Scholz 1990), which means that education administration at local levels lacked the professional expertise required to use key indicators of school planning as part of their organisational routines.

These differences in state organisation and political culture can be expected to have effects on the numeracy of both administrative personnel and the public. In order to capture these effects, we consider it useful to distinguish between a general and a context-specific concept of numeracy. By general numeracy we mean the 
ability to perform basic arithmetic calculations. In contrast to this general concept, we define democratic numeracy as the ability of citizens to use key quantitative indicators for collective (or private) decision-making and public deliberation about diverging political interests (cf. Kelman 1987). Historical evidence on the process of introducing bookkeeping practices in a numerically-literate population supports such a distinction between a general and a context-specific concept of numeracy. It suggests that generally numerate people (and organisations) acquire contextspecific numeracy only through formal and informal learning processes (Lampland 2010). Democratic numeracy can then be regarded as a specific dimension of a more general democratic capability of social actors which implies their active participation in collective decision-making, and also that they contest policy decisions. Applying this argument to the process of political transformation in Eastern Germany, we expect similar learning processes to take place. As the federal structure of the education system and corresponding forms of democratic school planning were not implemented in Eastern Germany until after reunification, we hypothesise the following:

$\mathrm{H} 2$ : The longer a democratic political system exists, the more important key administrative indicators will be for the responsiveness of school infrastructure policy to demographic change and the public representation of these decision processes (democracy hypothesis).

As an element of the process of establishing a democratic political culture, both policy makers and the public have to become acquainted with the routine use of key indicators. Key indicators recursively link democratic decision-making and public debate by providing stable "objects" to be referred to.

\subsection{School closures in the public debate}

After having elaborated the importance of quantitative indicators for the construction of demographic problems and the democratic numeracy of involved actors as a precondition of an extensive quantification of politics, we would like to focus on the representation of potential school closures in the mass media. We will argue that administrative and social conventions of classifying the school system shape public attention and deliberation.

The mass media follow their own criteria of selection (Luhmann 1996). The product of a mass media-attuned public is to establish particular topics (whilst ignoring others) with the effect of creating a certain agenda of publically-known topics at a given time which can be referred to. Hence, public attention itself is a source of power in political processes because it facilitates communication about certain topics. From the point of view of democratic theory, the mass media can be regarded as responsive to their environment insofar as they present a structurally-equivalent picture of political positions and political processes (Gerhards 1999). This does not refer to a complete set of issues, but to the transmittance of political needs for decision-making and public agenda (cf. Luhmann 1994). It has been shown in empirical terms that national newspapers tend to portray speakers, topics and parliamentary debates in a responsive way (Gerhards 1999; Soroka/Wlezien 2015). Local newspa- 
pers present content quite neutrally. Political elites are however quoted more often than are unorganised interest groups (Ne/ler 1999). In other words, local newspapers seem to display a social power bias in the sense that their ability to set public agendas tends to reinforce the status quo of power. Such self-reinforcing processes have been captured in other fields by the concept of cumulative advantages (Merton 1988). How can this assumed pattern of discourse be related to school closure processes?

From our point of view on the German school system, two dimensions of power relations are relevant. First, international research showed that formal and informal school planning procedures ascribe more power to political and administrative decision-makers than they do to pupils and parents (Frank 2011; Basu 2007; Bondi 1987). Local newspapers tend to include the views of decision-makers more often than those of pupils and parents because collectively-binding decisions by definition create news in the sense of new circumstances that deserve public attention. Secondly, stratified school systems are characterised by differences in social prestige conferred on each school type. These differences in social prestige are very often of historical origin. At the top of the hierarchically-differentiated German secondary school system, the Gymnasium (comparable to grammar schools in the UK) is the most prestigious school type (Tenorth 2008). Differences in prestige become entrenched over time through official classification systems as they are codified in school laws, official statistics or central definitions of places. ${ }^{4}$ These classifications are used in social evaluations as they occur in families' school selections, companies' location arrangements as well as in political-administrative decisions on education infrastructure. Support from various stakeholders has led to an expanding role of the grammar school in the German school system (e.g. Lundgreen 2000). Despite this expansion, the grammar school still retains a somewhat exclusive character, thus nurturing the prestige of the institution. Children of parents from a high socio-economic background are four times more likely to attend this school type than are those from a low socio-economic background (62 vs. 15 percent; Autorengruppe Bildungsberichterstattung 2014: 76). However, conventionalised forms of evaluating secondary school types are not static, but in fact evolve as they become subject to competition and critique, on the one hand (Zymek et al. 2011), and new distinctive practices at the top of the hierarchy, on the other hand (UIIrich 2014).

The unequal social prestige attached to different school types in a stratified school system seems to be especially relevant when it comes to demographicallyinduced problems of school infrastructure policy, given that different school types might compete for the same resources in such a situation. While we argue that key administrative indicators constitute demographic problems, they do not determine the decisions which are to be taken. In spite of indicators of organisational viability activating routines of school closure, there always remains some room for political discretion (which on a higher level also includes changes to or suspension of exist-

4 In the central place hierarchy of Saxony-Anhalt, for example, only municipalities of at least "intermediate centrality" are typically entitled to host a grammar school. 
ing thresholds - as in the 1980s for example in Western Germany [Derenbach/Gatzweiler 1988]). In the context of a potential school closure, a stronger presence in the mass media is likely to be helpful when expressing protest against an announced closure. We hence expect a power bias with respect to the relationship of administrative practice and public discourse:

H3: The presentation of school closures in local newspapers privileges the views of interest groups connected with more prestigious secondary school types over views related to other secondary schools (power hypothesis).

\section{Data and methods of analysis}

The empirical perspective of this article highlights the question of the responsiveness of school infrastructure in regions with a declining population, as the supposed mismatch between cohorts that are amenable to education and school infrastructure might induce collectively binding decisions. The portrayal of these decision processes in local newspapers is in the focus of this study.

Saxony-Anhalt was chosen for our case study because it is the German state which has undergone the highest population loss since the democratic revolution in 1989. Demographically-induced problems should therefore be clearly observable. The article reflects analyses of three data sources: First, the school lists of all schools providing general education in the years from 1991 until 2014; second, all relevant legal texts and documents on debates in the parliament of Saxony-Anhalt; and third, a corpus of 1,283 newspaper articles on the topics of "school closure" or "school planning" from the archives of the Mitteldeutsche Zeitung (MZ) for the years 1990 to 2014. The MZ is the largest local newspaper in Saxony-Anhalt, dominating the press in the southern part of the state. Table 1 gives an overview of our empirical design, followed by a more detailed description of data collection and analysis procedures. ${ }^{5}$

\subsection{Secondary data analysis of school lists}

In Germany, education policy lies within the competence of the states (Länder). The states are responsible for laws and for appointing teaching staff in general education. School buildings and their maintenance staff are the responsibility of the municipalities. Procedures of school planning, which according to our theory supposedly mediate the responsiveness of school infrastructure to demographic change, differ between German states (Rösner 1999; Winkler 2011). In Saxony-Anhalt, there are currently 14 districts (Kreise) and non-district towns (kreisfreie Städte) that have the competence to formulate school planning within the legislation of the state. Administrative decisions on single schools in the time interval 1991-2014 can only

5 The data collected will be made available for secondary analyses at the Data Service Center for Business and Organizational Data (DSZ-BO) in Bielefeld (Bartl et al. 2016). 
Tab. 1: Overview of data and methods used

\begin{tabular}{|c|c|c|c|}
\hline Source & Period & Data & Method of analysis \\
\hline $\begin{array}{l}\text { Statistisches Landesamt } \\
\text { Sachsen-Anhalt } \\
\text { (Sachsen-Anhalt Regional } \\
\text { Statistical Office) }\end{array}$ & $1991-2014$ & Official school lists & Descriptive statistics \\
\hline $\begin{array}{l}\text { Gesetz- und Verordnungs- } \\
\text { blatt für das Land } \\
\text { Sachsen-Anhalt; } \\
\text { Schulverwaltungsblatt für } \\
\text { das Land Sachsen-Anhalt } \\
\text { (Law and Ordinance } \\
\text { Gazette for the State } \\
\text { Saxony-Anhalt; School } \\
\text { Administration Gazette for } \\
\text { the State Saxony-Anhalt) }\end{array}$ & $1991-2014$ & $\begin{array}{l}\text { School laws and } \\
\text { related legislation }\end{array}$ & $\begin{array}{l}\text { Qualitative content } \\
\text { analysis }\end{array}$ \\
\hline Saxony-Anhalt Landtag & $1991-2014$ & $\begin{array}{l}46 \text { documents from } \\
\text { the parliament of } \\
\text { the state related to } \\
\text { school legislation }\end{array}$ & $\begin{array}{l}\text { Qualitative content } \\
\text { analysis }\end{array}$ \\
\hline DuMont & $1990-2014$ & $\begin{array}{l}\text { 1,283 newspaper } \\
\text { articles on "school } \\
\text { closure" or "school } \\
\text { development } \\
\text { planning" from } \\
\text { the archives of the } \\
\text { Mitteldeutsche } \\
\text { Zeitung (MZ) }\end{array}$ & $\begin{array}{l}\text { Qualitative and } \\
\text { quantitative content } \\
\text { analysis, hermeneutic } \\
\text { interpretation of } \\
\text { crucial sequences }\end{array}$ \\
\hline
\end{tabular}

be approximately reconstructed due to the lack of an encompassing data source. School lists seem to be the best data source for this reconstruction. Even if school lists do not provide information about debates on alternatives and decision processes, they at least document the results of these decisions.

School lists of a German state allow for the identification of all schools existing at a given time. Hence, matched school lists make it possible to construct panel data at the level of individual organisations, and to observe single population events (i.e. school closure and school inauguration). ${ }^{6}$

6 A precondition for a correct identification of a school closure or a school inauguration is that the analytical definition of such an event is identical to the administrative assignment of school numbers. This is not always the case in the school list used. A new school number was assigned in a few cases because the school form or organising institution changed. A comparison of aggregate data with school list data showed that aggregate data slightly underestimate the number of relevant population events, whereas school list data slightly overestimate the number of closures and inaugurations. Because both data sets lead to similar observations of the processes of interest, we decided to use school list data because they include more information. 


\subsection{Documentary analysis}

Many structural shifts documented in official statistics can only be adequately interpreted by paralleling them with relevant legal regulations and political debates. In this article, the official gazettes of the state of Saxony-Anhalt were consulted for the legal dimension, ${ }^{7}$ and for debates 46 documents of the state parliament were retrieved from its databank through a keyword search (Landtag von Sachsen Anhalt 2015; cf. Bart/ 2016). These data were mainly taken into account as supplementary data for the media analysis.

\subsection{Analysis of the local press}

The text corpus of the content analysis of the local press consists of 6,092 articles from the years 1990-2014 in the MZ. Articles were drawn by keyword selection from the archive of DuMont (publisher) using print material only. The keywords "Schulschließung" (school closure) and "Schulentwicklungsplanung" (school development planning) produced 1,025 and 5,067 hits, respectively. These 6,092 articles constitute the universe of the content analysis, which targets discussions regarding imminent, decided, or averted school closures. Due to the limited resources of the research, a random sample of approximately 1,000 articles was sought, amounting to one-sixth of the universe and approximately 40 articles per year observed. To represent the time variation in the published articles, a stratified random sample was drawn proportional to the annual distribution of hits (cf. Diekmann 2009: 386-387). Due to the particular relevance of the transformation process for school infrastructure policy in Eastern Germany, the entire article universe of the years 1991-1995 was retained in the sample of the quantitative content analysis.

A code book with 107 codes and sub-codes was developed for the quantitative content analysis based on theoretical criteria and qualitative content analysis. A final trial of parallel coding of 14 articles with three coders resulted in an 83 percent coefficient of concordance (out of 4,494 possible concordances). Out of the 1,283 articles selected, 828 had valid content which was used in the final analysis.

Some articles that were considered to be especially relevant were analysed in depth using hermeneutic interpretation techniques such as strictly sequential reading, the extensive development of interpretations, and the systematic examination of their compatibility with the remainder of the text (Reichertz 2010: 580).

\section{$4 \quad$ The practice and discourse of school closures}

The empirical part of the present article will start by clarifying whether decisions on school closures are tackling demographically-induced problems, and how re-

7 Gesetz- und Verordnungsblatt für das Land Sachsen-Anhalt: Law and Ordinance Gazette for the State Saxony-Anhalt; Schulverwaltungsblatt für das Land Sachsen-Anhalt: School Administration Gazette for the State Saxony-Anhalt). 
sponses are shaped by key administrative indicators $(\mathrm{H} 1$ : problem constitution thesis); second, how democratic numeracy evolves in a temporal perspective $(\mathrm{H} 2$ : democracy thesis); and third, how public discourse represents power relations in school infrastructure policy (H3: power thesis). The following section begins with an examination of the first two hypotheses because they are intrinsically interrelated.

\subsection{Key administrative indicators and responsiveness}

Due to the very rapid onset of the fertility decline in Eastern Germany after the opening of the Wall in November 1989 and the rapid shift of lifetime patterning of births, the drop in the total fertility rate in Eastern Germany between 1990 and 1994 was one of the sharpest ever recorded in history. The demographic change in the form of a decline in the age cohort size of school beginners was therefore massive, as Figure 1 shows.

The sudden drop in fertility at the onset of the transformation period impacted on schools with a time lag: Within just four years, the number of pupils starting primary school at the age of six dropped to half its size in relation to the school admission figures at the beginning of the 1990s (Fig. 1). The timing of the decline itself is also noteworthy: Starting at a slow pace in 1994, the most pronounced decline did not take place until between 1996 and 1997. Figure 1 shows that a similarly sharp

Fig. 1: School-age population in Saxony-Anhalt (1991-2013)

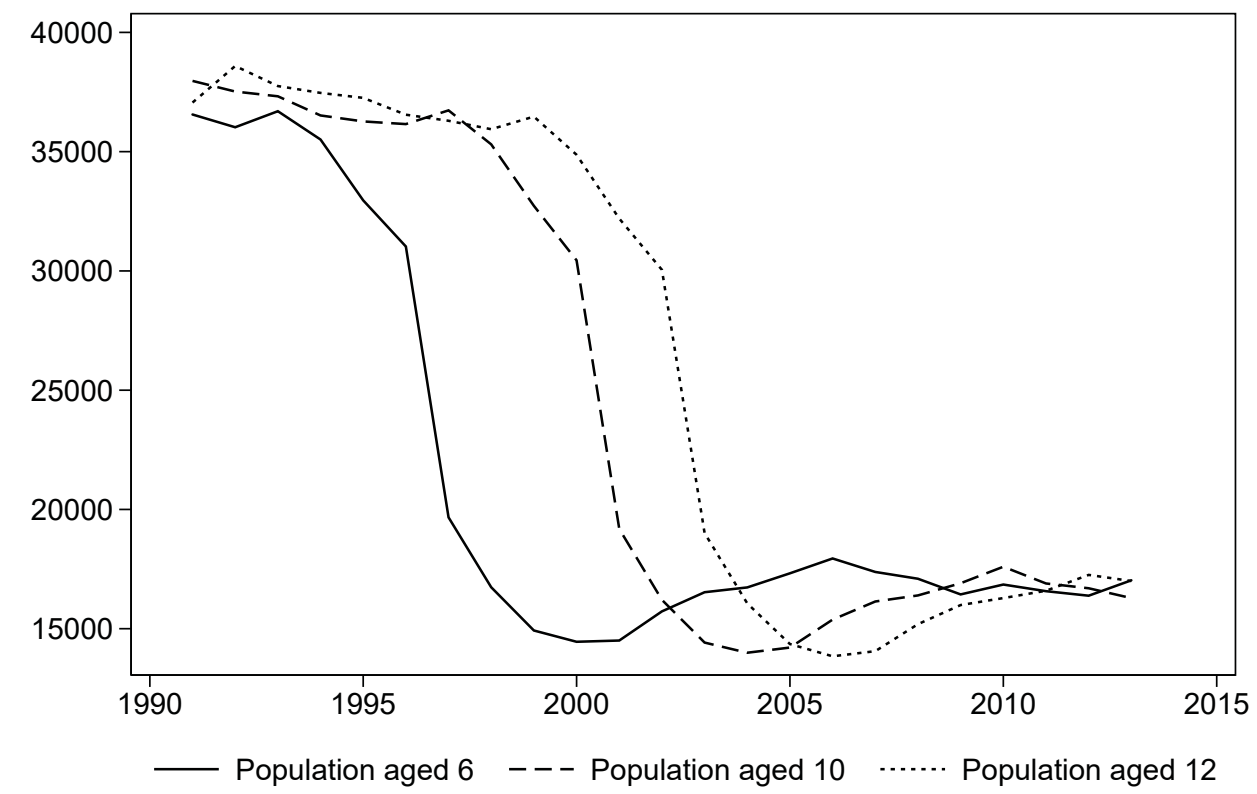

Source: Own compilation based on Statistisches Landesamt Sachsen-Anhalt 2010; Statistische Ämter des Bundes und der Länder 2015 
drop in the number of pupils starting secondary school at age 10 or 12 took place at approximately the beginning of the new millennium. We can conclude that the demographic conditions changed dramatically for primary schools in about 1996, and in secondary schools after 2001. Since we assumed that population statistics might be used in administrative practice, we will be examining whether this temporal pattern re-emerges in the timing of school closures and press reports on school closures.

Looking initially at the development of general education schools in SaxonyAnhalt, three developments are significant. First, the transformation from a communist regime to democracy and capitalism by incorporation meant a change of institutions in a very short time for the Eastern German education system (Sackmann 2010b: 179) which resulted in an immediate 55 percent increase in the number of schools on the territory of Saxony-Anhalt (Fig. 2). The comprehensive school system of the German Democratic Republic (GDR) consisted of an obligatory polytechnical secondary school (grades 1-10, Polytechnische Oberschule) and a highlyselective extended secondary school (grades 11-12, Erweiterte Oberschule). This system was replaced in the transformation process by a slightly modified version of the stratified Western German school system, with some minor variations occurring between the Eastern German states. The new school system in Saxony-Anhalt was comprised of a comprehensive primary school (Grundschule, grades 1-4), an integrated lower secondary school hosting a basic and an intermediate school track, which constituted an institutional innovation (Sekundarschule, grades 5-9/10), grammar schools containing the academically most demanding school track at the lower and upper secondary levels (Gymnasium, grades 5-12/13), and special education schools. ${ }^{8}$ The discretionary growth in the number of schools and school types created a particularly vulnerable system of education infrastructure, and in fact became a precursor to a contrary development. Second, the initial increase in the total number of schools is followed by a steady decrease until the end of the period analysed. Third, the decline in the number of schools occurs in waves and affects some school types more than others, with closures of primary and integrated secondary schools being the most frequent in absolute numbers. With respect to school closures, as a response to demographic decline, the first wave occurs long before demographic numbers would have indicated demographic problems. School closures before 1995 almost exclusively affect integrated secondary schools, while demographic problems for this school type would not have been expected until the beginning of the new millennium. How can we explain school closures before 1996 (vertical line in Fig. 2)?

In order to investigate the reasons for school closures, we first took a look at the public discourse. Figure 3 shows waves of public attentiveness to the topic of school closures for the period of observation: There are peaks in 1996, 2000,2003, 2009 and 2014. Astonishingly, there are no articles mentioning school closures in

8 For the sake of clarity, we omit four comprehensive schools and two Steiner schools in the transformation process. 
Fig. 2: Total number of schools on the territory of what today is Saxony-Anhalt (1989-2014), after 1990 also by school type

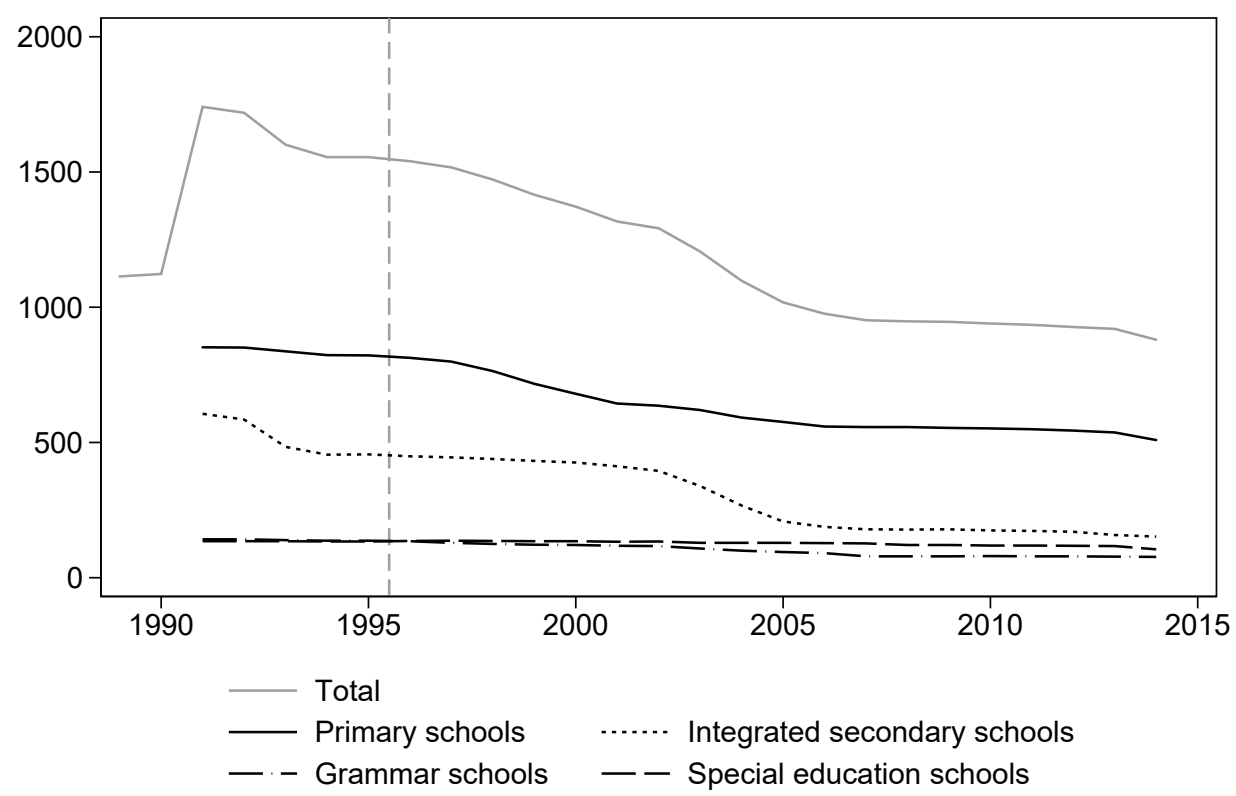

Source: Own compilation based on Statistisches Landesamt Sachsen-Anhalt 2016, 19912014

the interval between 1990 and 1992, despite around 20 closures occurring from 1991 to 1992.

As a further step towards answering the question of school infrastructure policy responding to demographic decline, the number of articles on school closures is systematically compared to the annual number of school closures registered in the school list data set (Fig. 3). The total number of schools in general education decreased continually during the period of observation (Fig. 2). However, the process is discrete with regard to the annual numbers of school closures. The temporal pattern of school closures is partially inconsistent not only with the demographic development, but also with the temporal distribution of newspaper articles on this topic. To help compare practices in school closures and public discourses on them, three temporal phases have been differentiated and marked with vertical lines in Figure 3. The first period, 1990-1995, is characterised by a large number of school closures, which receives almost no attention in the press. The second period, 19962007 , demonstrates a large number of school closures, flanked by a large amount of media coverage. In the third period, 2008-2014, a small number of school closures is accompanied by a disproportionately high degree of attentiveness in the press. 
Fig. 3: School closures (1991-2014) and articles on school closure in the Mitteldeutsche Zeitung (1990-2014) by year of publication

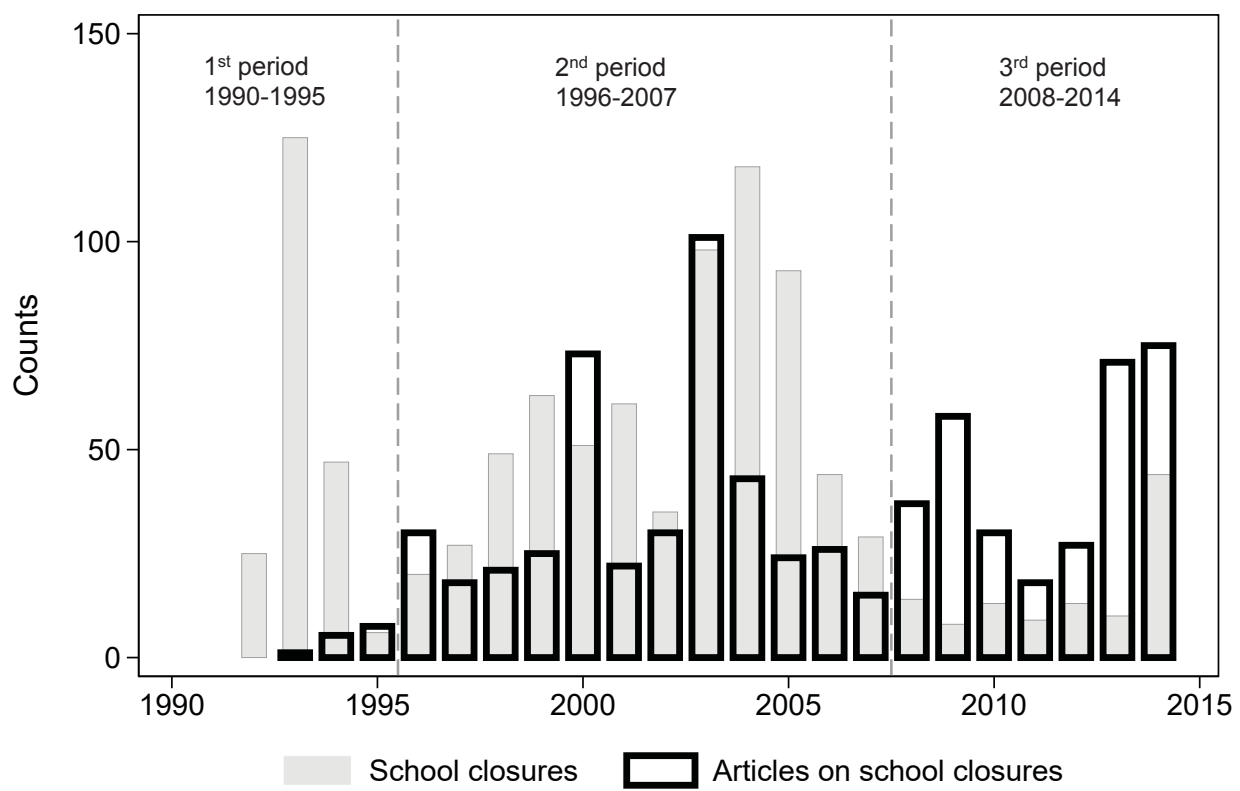

Source: Own compilation based on Statistisches Landesamt Sachsen-Anhalt 1991-2014; DuMont 2015

\subsubsection{Period one: Many closures, few reports}

School closures in the 1990-1995 period do not correspond to demographicallyinduced problems because the cohorts of typical school age were still large at that time. They are a by-product of the transformation of the education system formerly practised in Eastern Germany. As additional, new school types were introduced, the number of schools increased (Fig. 2). Figure 4 shows that this transformation immediately led to a massive drop in the average number of pupils per school as soon as in 1991. Whereas schools in the GDR tended to have approximately 350 pupils per school, the switch to a stratified secondary school system streaming pupils into different education tracks at age 10 or 12 immediately produced a school system of approximately 250 pupils per school in 1992. School sizes were even lower in the less highly-populated areas of Saxony-Anhalt. These rather small schools (in an international perspective; cf. Lee 2006) were quite prone to closure because the districts were not forced to establish formal school planning procedures until 1993, after a period of "provisional planning" (Kultusministerium Sachsen-Anhalt 1991). The new districts were obviously unfamiliar with the new school planning procedure, as documented by the fact that the Education Ministry had to publish practical guides for planning procedures (Kultusministerium Sachsen-Anhalt 1992b). 
Fig. 4: Average number of pupils per school in Eastern and Western Germany (1975-2012/2014)

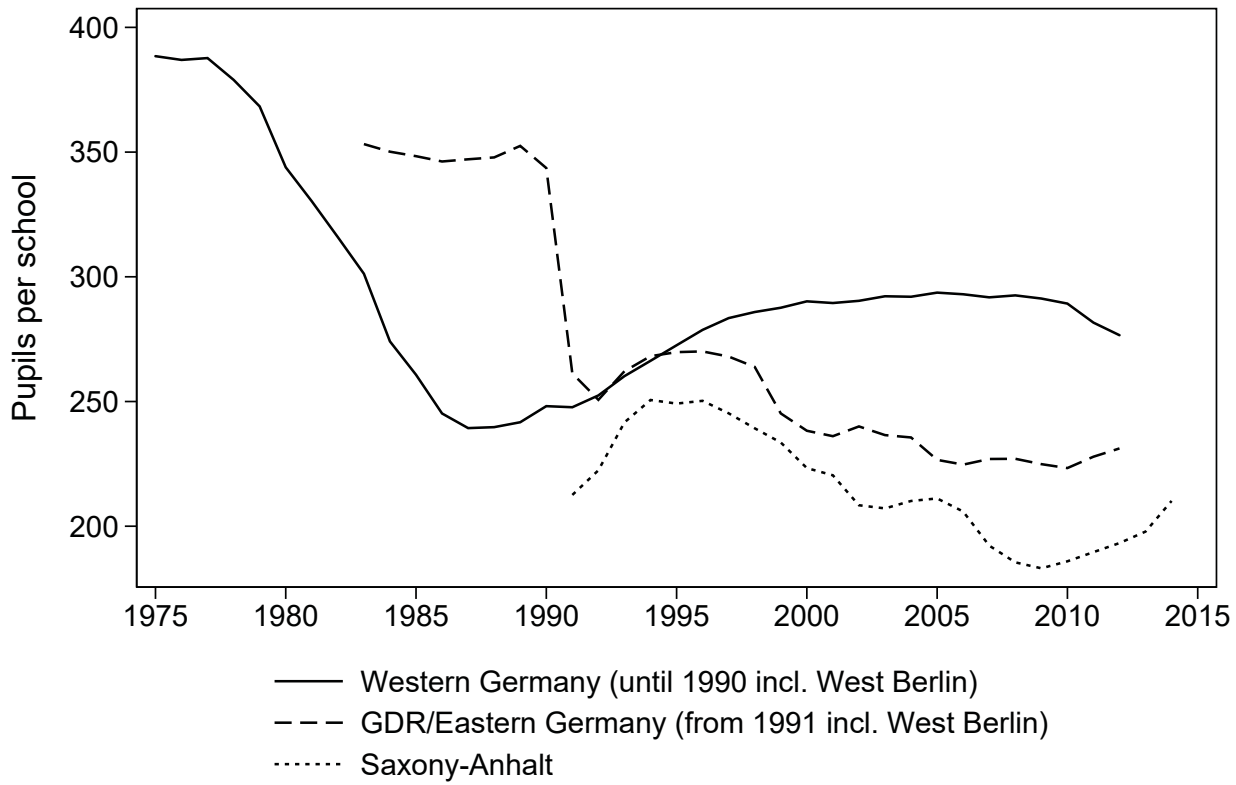

Source: Own compilation based on Statistisches Bundesamt 1975-2013; Statistisches Landesamt Sachsen-Anhalt 1991-2014

Specific for each school type, the standard amount of streams (Zügigkeit) and a minimum average class size (Klassenfrequenzrichtwert) were now a formal requirement for the viability of a school (Kultusministerium Sachsen-Anhalt 1991: 39). This minimum could be undercut in exceptional cases until a second minimum level was reached. However, the official publications of the state of Saxony-Anhalt did not mention any explicit minimum levels of average class size. Only a range was defined between which class sizes could fluctuate (e.g. Kultusministerium Sachsen-Anhalt 1992a). One can conclude that no clear-cut administrative viability limit was fixed (for schools) in this phase, and that none could be precisely deduced from given regulations on class sizes.

Other sources however provide a more comprehensive picture of the practice of the administration with regard to directives for school planning. One answer, given by the CDU/FDP government of the state to an interpellation submitted by the opposition PDS parliamentary group, reveals that minimum numbers for schools were employed for the first formal school planning. The lower limit for primary schools in 1993 was 60 pupils, for integrated secondary schools 250 and for grammar schools at grade 5-10 432 pupils (Landtag von Sachsen Anhalt 1993: 3). The answer also makes it clear that numerous schools had numbers below these minimum levels at that time, and were therefore threatened with closure. This was especially the case 
for integrated secondary schools, which in many instances had replaced the comprehensive polytechnical schools of the GDR, but had lost a significant number of pupils to primary schools and grammar schools. The state government justified its minimum levels with educational goals. The aim is

"for the uniform socialist school system of the former GDR to be replaced by a modern, efficient multi-tier school system. (...) To fulfil the requirements of differentiated tuition, school sizes must be reached that both provide the planned instruction and facilitate different school streams from a teaching and financial perspective" (Landtag von Sachsen-Anhalt 1993a: 1-2; translated). ${ }^{9}$

This parliamentary debate was reported on in a newspaper article. It is one of the very rare articles on school closures in the 1990-1995 period. It reads as follows:

"The PDS fears that the extinction of schools in Saxony-Anhalt will continue. (...) Ms. Hein demanded a rethinking in school policy because pupil numbers would fall rapidly every year, starting from 1997. Renewed school closures would lead to longer journey times for children. (...) In the school year 1993/94, the bodies maintaining schools will already close 16 primary schools, 100 integrated secondary schools, 3 grammar schools and 17 vocational schools. (...) The state government stresses in its answer that school planning has so far abstained from making radical cuts. School planning will consequently require municipalities to achieve the required school sizes in 1995/96. Until then, exceptional rulings that refer to region and situation are possible." (MZ_1993_11_11; translated)

It is interesting to note the three frameworks that are defined in the entire newspaper article: a) The PDS opposition party calls school closures an "extinction of schools", which dramatises institutional procedures by giving the organisation a personality that one can mourn. b) Back in 1993, Ms. Hein, as the speaker of the opposition party, gave the processes a demographic meaning ("pupil numbers ... fall ... starting from 1997") in an effort to underline the importance of discussions on the current topic for the future. c) The state government de-dramatises by referring to "exceptional rulings that refer to region and situation". Especially the last point, "situation", is very vague and corresponds to a whole range of aspects to be considered (Kultusministerium Sachsen-Anhalt 1993: 163). We therefore conclude that the state government is avoiding setting definite rules in order to obtain a maximum range of discretion when deciding on each individual case. As Bourdieu (1990) has shown, maximum power of local clientele policy is achieved by implementing rules that allow maximum arbitrariness in case-by-case decision-making. Procedures that allow decisions with reference to undefined circumstances of "situation" do provide this mode of policy.

A characteristic of the 1990-1995 period is that there are almost no contemporary newspaper articles on the large number of school closures. A detailed analysis of one of the small number of articles that did appear shows why the press

9 All quotes from primary sources were translated from German into English by the authors. 
are unresponsive to closures: Even the opposition does not (successfully) pick out school closures as a central theme of transformation policy. The opposition shifts the meaning of school closures to a demographic event that will happen four years later. Furthermore, the policy of the government to set discretionary rules that are negotiated in informal networks keeps the topic out of the press limelight. As the structure of the press at that time was still being established (Schneider et al. 1997; Thomaß 2015), the press itself did not independently make an agenda on school closures. The topic was even absent from most of the academic debates in Germany during this period (one exception is: Budde/K/emm 1992). In sum, during the first period, pressure for local decisions on school maintenance stemmed from decisions made through the transformation process and the subsequent application of organisational limits of viability. There was no demographic problem. However, these indicators were set and implemented somewhat shielded from public scrutiny, thus reflecting a limited level of democratic numeracy on the part of the actors involved.

\subsubsection{Period two: Many closures, many reports}

Press coverage of school closures grew in intensity after 1995. A closer look into the content reveals that most reports now even anticipate the events. The peaks in coverage in 1996, 2000 and 2003 anticipate the imminent closures in the following years (Fig. 3). This anticipative pattern of responsiveness can be explained by the temporal structure of school planning. By definition, school planning is a prospective procedure. In the 1990s, the districts were obliged to submit plans to education authorities for approval at the end of each calendar year in order to attain an actual basis for planning in the coming school year. Decisions that were prepared in this way were related to future developments in the number of pupils. Therefore, public discussion is geared before the demographic development manifests itself in organisations. This temporal pattern is also reflected in the seasonal pattern of newspaper reports on school closures in the local press, which peak in the months of November and December. As the deadline for conclusive school planning is set at the end of the year, the pressure to reach a decision increases in the last months of the year, and relevant newspaper articles cluster in this time interval.

The school closures however lag behind a shrinking school-age cohort size. Figure 1 showed that the primary school admission cohort fell most sharply in 1996/97 as a result of the rapid drop in the fertility rate in 1991. Negative migration balances between Eastern and Western Germany enhanced this development between 1991 and 2008 (Statistische Ämter des Bundes und der Länder 2011). The Saxony-Anhalt Education Ministry at first tried to react to this first demographic shock in the late 1990s by lowering the minimum size requirements for the formation of beginners' classes in schools. This reduction privileged grammar schools even more, as minimum levels for forming classes were suspended for them. The state government obviously acted on the presumption of a brief birth trough that could be countered by defining an exceptional phase. However, as later experiences were not convincing, minimum size levels were already increased in 1999, and the time horizon 
for school planning was enlarged from one year to five years (Kultusministerium Sachsen-Anhalt 1999).

The 1999 decree on medium-term school planning was amended in 2003 (Kultusministerium Sachsen-Anhalt 2003b), effecting the first complete five-year planning cycle to last from 2004 to $2008 .{ }^{10}$ This change of procedure gave rise to a need for discussion in the local press because the local subjects of the planning process were uncertain. The lack of self-confidence among this group is also revealed in 2000 and 2003 in the fact that the Ministry published practical guides for planners to reassure them in their practice (Kultusministerium Sachsen-Anhalt 2000, 2003a). Mass media responsiveness to school closures peaked in the same years (Fig. 3).

The large number of school closures in the 1996-2007 period can be interpreted as an intention to systematically consolidate the school infrastructure of SaxonyAnhalt through increased centralisation. At the same time as low-fertility cohorts entered secondary schools, medium-term school planning was introduced and regulations were tightened. As can be observed in the decrees of 1999 and 2003, Saxony-Anhalt Governments made up of different political parties ${ }^{11}$ followed this unitary response pattern. A systematisation of key indicators in this respect results in increased minimum levels of school size and the formation of beginners' classes, and - as a new criterion - the catchment population as a planning indicator:

"Above all, two magic number packages orientate school planning for the school years 2001/2002 until 2005/2006. Firstly, these are the new minimum numbers of pupils which the state has set: 60 pupils for a primary school, $160^{12}$ for an integrated secondary school, and 525 for a grammar school. Secondly, there are guiding numbers for the proportion of inhabitants in ratio to the number of schools in a territory: 2,000 inhabitants are thought to be needed for a viable primary school, 10,000 inhabitants for an integrated secondary school and 25,000 inhabitants for each grammar school." (MZ_2000_04_04; translated).

It is interesting to observe in this newspaper article that many indicators are explained and that the state is identified as the regulatory agency. In descriptive terms, the journalist gives a metaphoric framing of the new systematic use of indicators that refers to an intention of school planners: "two magic number packages". In this perspective, indicators produce results in infrastructure by transforming a chaotic reality into a clear-cut structure. Indicators are therefore seen as an efficient way to neutralise politics and to establish a kind of self-referential technocratic tool to produce predictable results in a policy process. Despite the fact that the state is

102003 was also the first year in which all minimum size requirements for the formation of beginners' classes were regulated in a separate circular decree by the Ministry (Kultusministerium Sachsen-Anhalt 2002).

11 The governing coalitions in Saxony-Anhalt were: 1990-1994 CDU, FDP; 1994-1998 SPD B90/ Grüne; 1998-2002 SPD; 2002-2006 CDU, FDP; 2006-2011 CDU, SPD; 2011-2016 CDU, SPD.

12 The minimum number of 160 pupils refers to grades $7-10$, beyond the orientation phase in the first two grades, which were part of the school system at that time. 
correctly mentioned as the regulator, the formula of "magic number packages" suggests that some agency of the state is transferred to the indicator itself (cf. Thévenot 2009). The following article shows how the pressure to act is implied in these indicators and perceived by local actors:

"The continuity of the integrated secondary school in Teuchern/Nessa is acutely threatened, the mayor stressed, and underlined his position with numbers. At present, there have to be at least 20 pupils from grades 5 to 7 in two classes. Further, there should be at least 160 girls and boys in a school from grades 7 to 10. According to Gieler [the mayor], this requirement could be fulfilled. The state demands as many as 240 pupils for grades 5 to 10 for the school year 2004/05. This criterion can be met with 256 pupils in the school. However, the minimum number of 40 pupils for two classes in grade 5 would no longer be reached." (MZ_2003_08_29; trans/ated).

In this article, the newspaper reports the perspective of a mayor for whom the list of indicators (and its imminent change) is a kind of checklist to observe the imminent threat of a school closure. Despite fulfilling three criteria positively, the mayor can point to a fourth criterion which he assumes will not be met in the following school year. As he presupposes that his audience would like to hold on to the school, the wording "is acutely threatened" indicates pressure to act either by accepting or protesting, or by finding ways to meet the criteria.

In sum, the increasing number of articles on school closures as a result of indicator-driven school planning is characteristic of the 1996-2007 period. Indicators are often used in this period as a technical justification for a mode of decision-making which leaves little scope for discretion.

\subsubsection{Period three: Few closures, many reports}

Somewhat surprisingly, the last period, 2008-2014, is characterised by a large number of articles, but the number of school closures was small. How can this pattern of press hyper-responsiveness be explained? According to our democracy hypothesis, a process of collective learning in the use of key administrative indicators should be at the heart of this process.

To test this hypothesis, all articles were coded according to the institutional frames of reference mentioned in the articles (Fig. 5). Institutional frameworks were differentiated between amendments to the school law or decrees, the mentioning of exceptional rulings, and the school planning procedure, which forms the institutional framework within which collectively-binding decisions are taken on school infrastructure and legitimised vis-à-vis different interest groups.

A uniform pattern exists with the exception of the last two years: Changes in legal frameworks applying to schools established by the state are rarely mentioned (in just 14.7 percent of all the articles). Administrative school planning procedures are referred to most often (in 72.9 percent of the articles), which form the prescribed framework for reaching decisions on school closures or finding alternatives. 28 percent of the articles relate to institutionalised exceptions. As school-hosting munici- 
Fig. 5: Institutional frameworks mentioned in newspaper articles on school closures in the MZ (1990-2014)



Source: DuMont 2015

palities have an interest in a school remaining in their territory, they will usually try to point to all the existing exemptions that could be applied within school planning. School planning is mentioned more often than are exemptions, as exceptional rulings on school closures cannot be referred to in all cases.

A peak in newspaper reports on school closures in 2009 (Fig. 3) marks the start of a new five-year-planning period (Kultusministerium Sachsen-Anhalt 2008b). The rules on the formation of beginners' classes were amended in a decree (Kultusministerium Sachsen-Anhalt 2008a). They introduced a geographical differentiation in the application of key indicators resulting in a lower level of school closures (Fig. 3). This change of rules is referred to in the following article:

"Further school closures are therefore ruled out in the near future, and the pupils in the district should not anticipate having to travel further to school.' For the SPD Member of the State Parliament (Landtag) and chairwoman of the Committee on Culture and Education of the Wittenberg district, Corinna Reinecke, this was the most important result of the new guiding indicators for school infrastructure planning, which were definitively set by the state last week." (MZ_2008_07_28; translated).

The rapid rise in the number of newspaper articles in the latter years of the 20082014 observation period is the result of an increasing number of conflicts between the local and the state level in Saxony-Anhalt. One reason for this is the raising of 
minimum primary school sizes (Kultusministerium Sachsen-Anhalt 2013). As is illustrated in Figure 5, the number of articles which mention state laws and decrees went up in recent years. An example of these new conflicts is given in this article:

"The chances to save small schools in the Burgenland district are poor under current circumstances. [...] This is the summary of what Rita Mittenzwei, spokeswoman on education of the SPD parliamentary group of the state, announced to her comrades and other members of the district group during a round table discussion on current school planning [...]. 'The legal situation is clear. No one wants to change this decree.' With these words, Rita Mittenzwei snubbed [district] delegates who had hoped for such an amendment, and who had previously campaigned vociferously. Because they - like the entire district council - do not want to see any more school closures. [...] The district has therefore applied for proceedings on the constitutionality of this decree of the Ministry of Education [Normenkontrollverfahren]. The official legal document only allows a minimum number of 120 pupils for specificallylisted individual integrated secondary school locations. This was set in relation to the population density. However, the minimum number of pupils for schools in the Burgenland district is set at 180, a number they will not reach in the next few years, whereas they would have reached more than 120." (MZ_2009_11_13; translated).

In this article, local politicians are already arguing in an experienced way on the ratios between indicators, exceptions and school closures. With formal exemptions, the policy of the state tries to take local particularities into account when reaching decisions for sparsely-populated districts (i.e. a reduced minimum of 120 pupils). An increase in local politicians' democratic numeracy level corresponds with the notion of defining one's own local interests and fighting for them. The article describes this as having "campaigned vociferously" in order to indicate that local politicians are engaging in open conflict, even within their own parties. To seek a judicial review of the case also indicates a mature level of competence with regard to the forms of democratic competition between interests. Exemption rules increase the room to manoeuvre. State-level politicians, like the Member of Parliament mentioned above, are increasingly being placed on the defensive by local politicians.

The amount of media coverage on school closures is increasing because conflicts of this kind are growing in number as differences of opinion are voiced in public. The paradox of a strong de-coupling between the frequency of school closures and the intensity of discourses on this topic in the press is resolved by a rationalisation process of political actors. The increasing time horizon of state government planning corresponds to an extension of the preventive protection time horizon of local politicians who debate in public, long before events are set to take place. In this constellation, even unlikely conflicts within factions and governments can break out, as other articles show as well (e.g. MZ_2014_10_18). In the last period of responsiveness observed between demographic change and school closures, not only the level of reports shifts from the local area to the sphere of the federal state, but the style of reports is also more prone to media coverage. Newspaper articles on the topic of school closures had read like administrative reports for many years. 
As conflicts grew in number, the news value of the information increased. In the article mentioned above, even a seemingly minor conflict on minimum school sizes of 52 or 60 pupils can be transformed into a heart-rendering tale of how important regulators are "fighting back tears" (MZ_2014_10_18).

The results obtained so far can be summarised as follows: The initial hypothesis stated that key administrative indicators would constitute demographic problems and create a need for collective decisions. A more specific second hypothesis argued that, in transformation societies, key administrative indicators would become more important over time as governance devices due to a collective learning process leading to heightened democratic numeracy. The empirical analysis basically confirms both hypotheses.

\subsection{Power relations of school infrastructure policy in the local press}

We argued in our power hypothesis that administrative and social conventions for classifying the school system would shape public attention and deliberation. This section will examine this proposition.

The content analysis shows that school closures are a topic that is seen as a local event in journalistic terms. The large majority of the 828 articles that we analysed appeared in the local pages of the newspaper studied, only 2.4 percent of all articles figured in the general edition of the MZ. The local character of the reporting is emphasised even more strongly by the locally-focussed nature of the articles' content. Only 1.1 percent of all articles cover the situation of the school infrastructure throughout the whole state of Saxony-Anhalt; all other articles concentrate on one single district or on a couple of districts. This locally-limited attribution of relevance is partly explained by the fact that districts are the subject of school planning. 72.9 percent of all articles mention a current or upcoming process of school planning as an institutional framework in the article. Only 14.7 percent of all articles refer to changes in the legal framework of the state. As the state sets the terms for school planning, the local newspaper applies a kind of local bias to its reporting, as it focuses on local actors and not on federal state rules. Despite the fact that the demographic development in the districts of Saxony-Anhalt follows similar patterns, and an identical constraint shapes planning which is fixed by the state, articles rarely make an agenda of school infrastructure beyond local relevance.

Districts (58.3 percent) and municipalities (44 percent) are therefore the main actors found in the articles on school closures; parents (23.9 percent) and pupils (10.5 percent) appear less often. Districts are the relevant decision-makers in formal terms. As the subject of the planning process, they are legally obliged to relate with municipalities as school building owners, as well as with parents and pupils. Districts therefore seek information on positions of the (sometimes divergent) interests of these actors, but they do not have to come to a joint decision. The federal state has the power to set the rules for school planning and to monitor their implementation. Despite this important regulatory function of federal state representatives, they are quite often "invisible" in the articles: Only 19.4 percent name actors of the federal state, of which the larger part (14.7 percent) refers to the changes in legal 
frameworks which have already been mentioned. Existing or changed administrative size regulations are only given in concrete figures in 7.6 percent of the articles.

How are different types of schools represented in the articles on school closures? If our power hypothesis is correct, well-organised interest groups will be reported on more often. There will therefore be more articles on imminent school closures of higher-prestige school types than on those of lower prestige. The question can be answered by consulting Table 2. It relates all the school closures that have been identified to the number of articles on school closures, as well as to articles on efforts to rescue schools.

Tab. 2: $\quad$ Closures of general education schools in Saxony-Anhalt (1991-2014) and articles on this topic in the Mitteldeutsche Zeitung (1990-2014), by school type

\begin{tabular}{lccccc}
\hline & $\begin{array}{c}\text { Schools in } \\
1991 \\
\%\end{array}$ & $\begin{array}{c}\text { Schools in } \\
2014 \\
\%\end{array}$ & $\begin{array}{c}\text { School } \\
\text { closures } \\
\%\end{array}$ & $\begin{array}{c}\text { Articles on } \\
\text { school closure } \\
\text { in MZ } \\
\%\end{array}$ & $\begin{array}{c}\text { Articles } \\
\text { on efforts } \\
\text { to rescue } \\
\text { schools in MZ } \\
\%\end{array}$ \\
\hline $\begin{array}{l}\text { Primary school } \\
\begin{array}{l}\text { Integrated } \\
\text { secondary school }\end{array}\end{array}$ & 48.9 & 57.8 & 40.7 & 39.3 & 47.4 \\
$\begin{array}{l}\text { (Sekundarschule) } \\
\text { Grammar school }\end{array}$ & 34.8 & 17.3 & 45.8 & 39.4 & 37.4 \\
$\begin{array}{l}\text { (Gymnasium) } \\
\begin{array}{l}\text { Special education } \\
\text { school (Förderschule) }\end{array}\end{array}$ & 7.8 & 11.9 & 4.2 & 3.9 & 1.3 \\
$\begin{array}{l}\text { Other schools } \\
\text { Total (\%) }\end{array}$ & 0.3 & 4.2 & 1.5 & 0.4 & 2.6 \\
\begin{tabular}{l} 
Total (N) \\
\hline
\end{tabular} & 100 & 100 & 100 & 100 & 100 \\
\hline
\end{tabular}

* Comprehensive schools, Steiner schools, community schools (Gemeinschaftsschulen, introduced in 2013).

* The total number of closures and the number of schools in 2014 do not add up to the number of schools in 1991 due to newly-established schools and some changes to school identification numbers for administrative reasons.

*** A single article may mention large numbers of closures per type of school. The maximum count was one in each article. If specific school closures appeared in different articles, they were counted repeatedly.

Source: Own calculations based on Statistisches Landesamt Sachsen-Anhalt 1991-2014; DuMont 2015

The table shows that primary and integrated secondary schools amount to almost 90 percent ( 86.5 percent) of the more than one thousand schools closed since 1990. In contrast, grammar schools and special education schools were rarely closed. Comparing school closure practices with press reporting, Table 2 indicates 
that reports are biased with regard to integrated secondary schools: Reports on their closure are less likely than are reports on the closure of grammar schools, which attract a disproportionate amount of attention. Reports on primary schools and special education schools are similar in number to closures. Press coverage on efforts to rescue schools is even more unbalanced against integrated secondary schools. There are disproportionally more articles on efforts to save grammar schools and primary schools. These numbers reflect among other elements the social prestige which distinguishes grammar schools from integrated secondary schools.

However, prestige seems not to be the only determinant of public attention. Primary schools are supported on an equally high level because the guiding idea of the decentralised provision of primary education (as expressed in the frequently mentioned motif "short legs, short distances") is not shared by school planners and municipalities alone, but also resonates a general notion that young school children are a group that deserves special protection.

With regard to our power hypothesis, the results that have been obtained can be summarised by stating that local media coverage enhances the existing asymmetry of power between school types and the social groups which they tend to represent. The latter shows up in the fact that grammar schools disproportionally often cater for families from a higher socio-economic background (Autorengruppe Bildungsberichterstattung 2014: 76; Schwarz/Weishaupt 2014: 25), thus fuelling the social prestige traditionally ascribed to this school type. Hence, the spatial distribution of grammar schools is privileged by this kind of media responsiveness.

\section{$5 \quad$ Summary and discussion}

This article investigated the guiding question of whether - and how - responsiveness to demographic change is constituted in the education system. It was stated that, in the case of democratic politics, demographic problems have to first be established as relevant before there is a need for any collective decisions to be taken. According to this concept, the first hypothesis was that, in democracies, key indicators are crucial for establishing relevance because they are used to evaluate the results of previous policy and enable the need-based viability of existing programmes and organisations in a largely decommodified context to be monitored. A second hypothesis specified our first assumption for the context of societies in transition, stating that the relevance attaching to key indicators as governance devices should increase with the democratic numeracy of the actors involved. In a third stage within our theory of responsiveness, we stated that, in democracies, the media play an important role in the policy cycle as they observe societies selectively, and thereby establish issues. We hypothesised that press attention to education infrastructure policies will slightly increase power because reports on plans to close grammar schools (and to protest against it) will be more frequent than reports on other types of secondary school. 
The empirical study on the political-administrative practice of school closures, and reports on them in the media, was focused on the German state that was hardest hit by a decrease in population. The results that were obtained are interesting not least due to the extensive observation period from 1990-2014. This is even more so because democracy had been established in this Eastern German state at that time, after 57 years of dictatorship, so that the constitutive logic of democratic responsiveness could be observed throughout the observation period.

Our initial hypothesis of responsiveness to demographic change, for which key indicators are crucial in democratic systems, is supported. In hindsight, the empirical material allows a more precise analysis of its functioning and its developmental logic. The process that was observed of the democratisation of political responsiveness took place in three stages that were apparent in divergent patterns of the relationship between policy events and media coverage. Large numbers of school closures took place in the initial period from 1990-1995 with virtual media silence, whilst there is a higher concordance in the second period of 1996-2007 between the frequency of reports and the number of closures, whereas a high number of media reports occurs in the last period of 2008-2014 despite a relatively small number of closures. At first glance, it could be stated that there is a variance originating basically from public discourse. However, a closer qualitative and quantitative analysis reveals that this pattern reflects substantial changes in the practice of education infrastructure policy. We are of the view that this has broader implications.

The first period is characterised by unintentional effects of Reunification. The barely reflected adoption of the stratified Western German school system to replace the unified GDR system results in an inefficient increase in school organisations, long before a drop in birth rates reached the schools. In order to correct these measures, the number of school closures in the 1990-1995 period increases, despite the fact that organisational viability criteria are used in a relatively discretionary fashion. It is important to note for a general theory of political responsiveness that, in this case, numerous events occur without public discussion because the rules relating to school closures are not transparent. In hindsight, similar processes of a politically-induced over-supply can be observed in housing, where also unintended effects of transformation precede market crises in the form of a rise in the vacancy rate, later attributed to demographic processes. With regard to education, the number of school organisations was structurally increased by the introduction of a multi-tier system which produced a situation of over-supply, followed by a fall in demand (cf. Budde/Klemm 1992). In this respect, the later "demographisation" of the problem of school closures masks mistakes made in the transformation process.

Another aspect that needs to be noted for a theory of political responsiveness is that failing to use transparent key indicators when deciding on school closures transforms these into "occurrences" which are not the object of public reports and discussions. This kind of more arbitrary responsiveness is therefore more akin to forms found in autocratic orders than a certain bureaucratic form in fully-fledged democracies. In a similar vein, research on the transformation of local governments in Eastern Germany showed that public administration in the GDR was bound less 
by keeping written records than would have been expected, if one regards the GDR as having constituted a bureaucratic regime (Seibel 1993).

In the ensuing 1996-2007 period, the introduction of responsiveness to demographic decline by key indicators results in a rationalisation of political decisions. An increasing usage of population indicators is also an effect of democratisation processes. Indicators allow comparisons to be made between different local situations which can be objectified without privileging one population group over another. Key administrative indicators enable a transformation of occurrences into planning decisions. When it comes to school planning, key indicators allowed future conditions to be anticipated, initially with a time horizon of one year, subsequently extended to five years. Responsiveness to demographic change via key indicators is hence a systematic endeavour to formulate responses to anticipated future challenges; it is not a spontaneous response to a sudden, new problem. For this kind of need-based economic thought experiment, demographic data outperform other time series data because they are less affected by short-term external influences.

Two further features of responsiveness to demographic change by key indicators are highlighted in the 1996-2007 period. If key indicators are simply used as "statistical rules" (Starr 1987: 55), they will be able to de-politicise a topic. The whole pattern of media reports on school closures being restricted to local news (neglecting regulation at state level), and following administrative rules of school planning at the end of the year, displays the logic of technocracy. Key indicators can objectify political decisions and thereby avoid controversy. In this sense, such indicators are agents i.e. they are perceived as powerful stakeholders. When press reports talk about "magic number packages", the autonomy of these technical instruments is underlined.

However, key indicators have a potential for social experiments and learning because they can objectify problem analysis: Given for instance that the minimum size of primary schools was lowered in 1996-2000, it can be monitored whether a shortterm change in a viability indicator can bridge demographic troughs. If this turns out not to be the case, as was seen in 2001, normality can be restored. Because rule-based indicators enable one to formulate precise expectations, deviations from rules can be featured as social experiments. This enables collective learning. Whether societies are successful in using these rationalisations not only to raise formal rationality, but also to further material rationalisation, is decided when conflicts of interest arise.

The alleviation of collective learning as a dimension of responsiveness to demographic decline is accentuated in the final 2008-2014 observation period. The analysis showed that the periodic increase in media coverage on school closure is a result of an increase in the incidence of public conflicts. Both between the local and state levels, and within the state level, conflicts on key indicators arise independently of party factions. The tendency to see this topic as one of state policy is on the rise. A close analysis of articles shows that, both on the local and state level, democratic numeracy is improving insofar as the knowledge spreads on how indicators behave. The potential for using indicators for one's own purposes is therefore growing. Parallel to more public conflicts, a re-politicisation of key indicators is taking place 
as programme-setting decisions by the state are demanded and criticised. In this sense of more universal numeracy, responsiveness constituted by key indicators provides a chance to make decisions on programmes more transparent for interest groups, thereby alleviating open controversy. As in other studies on indicators (Rottenburg et al. 2015), we see that the effects of indicators are ambivalent: they de-politicise decisions in some periods, but in later periods they create a forum for reflected public debates on political goals.

With regard to the power thesis, i.e. media coverage of school closure processes, the initial hypothesis of power bias is basically supported: The proportion of reports on grammar school closures and their frequency is twice as high as the corresponding ratio of reports to closures in the case of integrated secondary schools. Also because of this tendency, the number of articles on school rescue strategies for grammar schools is disproportionally high. This accelerating effect on the vertical stratification of the supply structure is largely ignored when discussing the effects of demographic change on education structures: Lower secondary schools are not only more often closed in relation to decreasing population numbers, but there are also disproportionally fewer reports on their closure, and fewer controversies in the media on the closure. In relation to decreasing numbers of children, grammar schools are closed down disproportionally less often, also because there are more media reports on imminent closures, and there are more public discussions on strategies for rescuing them. ${ }^{13}$ Interestingly, this pattern of responsiveness indirectly furthers education expansion, as the spatial difference between the supply structure of grammar schools and other secondary schools is reduced. Because patterns of selective school closures reduce differences in proximity, arguments put forward by parents and pupils, which stress a higher proximity of integrated secondary schools in comparison to grammar schools, become less important.

In general, similar to the results of Gerhards (1999), our study shows a relatively weak bias of media responses to politics: The media depict existing structures of responsiveness relatively accurately, showing a slight bias towards existing power relations, and virtually never set a new agenda independently of existing structures.

\section{Acknowledgements}

We would like to thank Michael Eckert, Keno Frank and Hermann Budde for their valuable context information on school planning procedures, which was input in the early stages of our research. We also highly appreciate the comments made by the participants of the workshop on "Responsiveness" at the FIW in Bonn, where we had the chance to present and discuss our results in September 2015. The following colleagues generously invested their time to read an earlier version of this paper: Oliver Winkler, Oliver Arránz Becker, Christian Papilloud and Manfred Stock. Their

13 This conclusion is supported by initial results from logistic regressions on the organisation level, which will be part of another article on this topic. The results can be made available on request. 
critical questions and thorough advice contributed much towards sharpening our argument. We are also deeply grateful for the remarks of the editors of this special issue, Birgit Glorius and Birgit Leick, the editor of CPoS Frank Swiaczny, and two anonymous reviewers as well as for the copy-editing by CPoS. Furthermore, we would like to acknowledge the attentive and reliable support given by Clara Breyer during the coding process of the content analysis. We thank the state of SaxonyAnhalt for funding an important part of this study (Grant no. 5207/AD/0609M).

\section{References}

Anderson-Levitt, Kathryn M. 2003: A World Culture of Schooling? In: Anderson-Levitt, Kathryn M. (Ed.): Local meanings, global schooling. Anthropology and world culture theory. New York, NY: Palgrave Macmillan: 1-26.

Ares Abalde, Macarena 2014: School Size Policies. A Literature Review. OECD Education Working Papers 106. Paris: OECD [doi: 10.1787/5jxt472ddkjl-en].

Arnhold, Grit 2005: Kleine Klassen - große Klasse? Eine empirische Studie zur Bedeutung der Klassengröße für Schule und Unterricht. Bad Heilbrunn: Klinkhardt.

Autorengruppe Bildungsberichterstattung 2014: Bildung in Deutschland 2014. Ein indikatorengestützter Bericht mit einer Analyse zur Bildung von Menschen mit Behinderungen. Bielefeld: Bertelsmann.

Autti, Outi; Hyry-Beihammer, Eeva Kaisa 2014: School Closures in Rural Finnish Communities. In: Journal of Research in Rural Education 29,1: 1-17.

Barakat, Bilal 2014: A ‘Recipe for Depopulation'? School Closures and Local Population Decline in Saxony. In: Population, Space and Place 21,8: 735-753 [doi: 10.1002/ psp.1853].

Barakat, Bilal Fouad et al. 2011: Education, remoteness and population dynamics. In: Carson, Dean et al. (Eds.): Demography at the edge. Remote human populations in developed nations. International population studies. Farnham: Ashgate: 255-269.

Barlösius, Eva 2007: Die Demographisierung des Gesellschaftlichen. Zur Bedeutung der Repräsentationspraxis. In: Barlösius, Eva; Schiek, Daniela (Eds.): Die Demographisierung des Gesellschaftlichen. Wiesbaden: VS Verlag für Sozialwissenschaften: 9-36.

Bartl, Walter 2016: Schulentwicklungsplanung als ,governance device'. Eine Mixed-Methods-Analyse der Schulinfrastruktur in demographisch schrumpfenden Regionen. In: Liebig, Stefan; Matiaske, Wenzel (Eds.): Methodische Probleme der Organisationsforschung. Wiesbaden: Springer Gabler: 227-265.

Bartl, Walter; Sackmann, Reinhold; Breyer, Clara 2016: Indicators and Responsiveness to Population Decline: School Closures as Practice and Discourse in Saxony-Anhalt. Dataset. Version 1. Datenservicezentrum Betriebs- und Organisationsdaten (DSZ-BO). Bielefeld [doi: 10.7478/s0284.1.v1].

Basu, Ranu 2007: Negotiating Acts of Citizenship in an Era of Neoliberal Reform: The Game of School Closures. In: International Journal of Urban and Regional Research 31,1: 109-127 [doi: 10.1111/j.1468-2427.2007.00709.x].

Behnke, Nathalie 2009: Responsivität und Verantwortlichkeit der öffentlichen Verwaltung. In: Czerwick, Edwin; Treutner, Erhard; Lorig, Wolfgang H. (Eds.): Die öffentliche Verwaltung in der Demokratie der Bundesrepublik Deutschland. Wiesbaden: VS Verlag für Sozialwissenschaften: 45-64. 
Besley, Timothy; Burgess, Robin 2002: The Political Economy of Government Responsiveness. Theory and Evidence from India. In: The quarterly journal of economics 117,4: 1415-1451 [doi: 10.1162/003355302320935061].

Billger, Sherrilyn M. 2010: Demographics, fiscal health, and school quality. Shedding light on school closure decisions. IZA Discussion paper series. 4739. Bonn [http://ftp. iza.org/dp4739.pdf, 15.02.2016].

Birg, Herwig 2001: Die demographische Zeitenwende: Der Bevölkerungsrückgang in Deutschland und Europa. München: Beck.

Bommes, Michae/ 1999: Migration und nationaler Wohlfahrtsstaat. Ein differenzierungstheoretischer Entwurf. Wiesbaden: VS Verlag für Sozialwissenschaften.

Bondi, Liz 1987: School closures and local politics: the negotiation of primary school rationalization in Manchester. In: Political Geography Quarterly 6,3: 203-224 [doi: 10.1016/S0260-9827(87)80001-0].

Bondi, Liz 1989: Selecting schools for closure: theory and practice in 'rational' planning. In: Journal of Education Policy 4,2: 85-102 [doi: 10.1080/0268093890040201].

Bourdieu, Pierre 1990: Droit et passe-droit. In: Actes de la recherche en sciences sociales 81,1: 86-96 [doi: 10.3406/arss.1990.2928].

Brixner, Wolf 1972: Schulplanung im ländlichen Raum. Probleme regionaler Bildungsplanung. Dissertation. Tübingen.

Budde, Hermann; Klemm, Klaus 1992: Äußere Schulentwicklung in den neuen Ländern. Perspektiven und Gefährdungen. In: Rolff, Hans-Günter (Ed.): Jahrbuch der Schulentwicklung. Vol. 7. Weinheim: Beltz: 133-157.

Butterwegge, Christoph; Klundt, Michael 2003: Die Demografie als Ideologie und Mittel sozialpolitischer Demagogie? Bevölkerungsrückgang, "Vergreisung" und Generationengerechtigkeit. In: Butterwegge, Christoph (Ed.): Kinderarmut und Generationengerechtigkeit. Familien- und Sozialpolitik im demografischen Wandel. Opladen: Leske + Budrich: 59-80.

Carruthers, Bruce G.; Espeland, Wendy Nelson 1991: Accounting for Rationality: Double-Entry Bookkeeping and the Rhetoric of Economic Rationality. In: American Journal of Sociology 97,1: 31-69.

Cohen, Patricia Cline 1982: A calculating people. The spread of numeracy in Early America. Chicago: University of Chicago Press.

Derenbach, Rolf; Gatzweiler, Hans-Peter 1988: Sicherung der Schulstandorte unter veränderten Rahmenbedingungen - eine gemeinsame Aufgabe von Raumordnungs- und Bildungspolitik. In: Informationen zur Raumentwicklung 15,7: 407-416.

Desrosières, Alain 2005: Die Politik der großen Zahlen. Eine Geschichte der statistischen Denkweise. Berlin: Springer.

Deutscher Bildungsrat 1973: Strukturplan für das Bildungswesen. Empfehlungen der Bildungskommission. $4^{\text {th }}$ ed. Stuttgart: Klett.

Diekmann, Andreas 2009: Empirische Sozialforschung. Grundlagen, Methoden, Anwendungen. $20^{\text {th }}$ ed. Reinbek bei Hamburg: Rowohlt.

Döring, Peter A. 1977: Große Schulen - oder kleine Schulen? Zur Dimensionierung von Bildungseinrichtungen. In: Döring, Peter $A$. (Ed.): Große Schulen oder kleine Schulen? München: Piper: 15-40.

DuMont 2015: Printarchiv der Mitteldeutschen Zeitung (MZ). Sonderauswertung 1990 2014. Köln: DuMont. 
Egelund, Niels; Laustsen, Helen 2006: School Closure: What are the consequences for the local society? In: Scandinavian journal of educational research 50,4: 429-439 [doi: 10.1080/00313830600823787].

Elacqua, Gregory; Martínez, Matías; Santos, Humberto; Urbina, Daniela 2012: School closures in Chile. Access to quality alternatives in a school choice system. In: Estudios de economía 39,2: 179-202.

Elshof, Hans; Haartsen, Tialda; Mulder, Clara H. 2015: The Effect of Primary School Absence and Closure on Inward and Outward Flows of Families. In: Tijdschrift voor economische en sociale geografie 106,5: 625-635 [doi: 10.1111/tesg.12172].

Emigh, Jean R. 2002: Numeracy or Enumeration? The Uses of Numbers by States and Societies. In: Social Science History 26,4: 653-698.

Engberg, John; Gill, Brian; Zamarro, Gema; Zimmer, Ron 2012: Closing schools in a shrinking district: Do student outcomes depend on which schools are closed? In: Journal of Urban Economics 71,2: 189-204.

Ewen, Sophia 1997: Who pays for school closures? In: Public finance: 12-15.

Finnigan, Kara S.; Lavner, Mark 2012: A Political Analysis of Community Influence over School Closure. In: Urban Review 44,1: 133-151 [doi: 10.1007/s11256-011-0179-9].

Frank, Keno 2011: Schulentwicklungsplanung im demografischen Wandel. Am Beispiel der Kreise Dithmarschen und Steinburg. Kieler Arbeitspapiere zur Landeskunde und Raumordnung 52. Kiel: Universität Kiel.

Frommberger, Herbert 1974: Einführung: Die Stufenschule. Ein Leitfaden zur kommunalen Schulentwicklungsplanung. Stuttgart: Klett: 9-16.

Gerhards, Jürgen 1999: Wie responsiv sind die Massenmedien? In: Gerhards, Jürgen; Hitzler, Ronald (Eds.): Eigenwilligkeit und Rationalität sozialer Prozesse. Opladen/ Wiesbaden: VS Verlag für Sozialwissenschaften: 145-173 [doi: 10.1007/978-3-32289004-7 9].

Godinho, Ana Sofia 2012: School closures and community revitalisation: the case of Óbidos, Portugal. CELE Exchange. 2012/3. Paris: OECD [http://www.oecd.org/edu/ educationeconomyandsociety/centreforeffectivelearningenvironmentscele/Portugal. pdf, 15.02.2016].

Hattie, John 2005: The paradox of reducing class size and improving learning outcomes. In: International Journal of Educational Research 43,6: 387-425.

Heintz, Bettina 2007: Zahlen, Wissen, Objektivität: wissenschaftssoziologische Perspektiven. In: Mennicken, Andrea; Vollmer, Hendrik (Eds.): Zahlenwerk. Kalkulation, Organisation, Gesellschaft. Wiesbaden: VS Verlag für Sozialwissenschaften: 65-86.

Helbig, Marcel; Schmolke, Nico 2015: Bildungserfolg im Kontext demografischer Veränderungen. Wie die Bevölkerungsstärke des Geburtsjahrgangs Bildungswege beeinflusst. In: Zeitschrift für Soziologie 44,3: 197-214.

Jacoby, Eduard Georg 1959: Methods of school enrolment projection. Educational studies and documents 32. Paris: Unesco.

Jones, Gavin W. 1975: Educational planning and population growth. In: Robinson, Warren $C$. (Ed.): Population and development planning. New York: Population Council: 69-106.

Kaufmann, Franz-Xaver 2012: Konzept und Formen sozialer Intervention. In: Albrecht, Günter; Groenemeyer, Axel (Eds.): Handbuch soziale Probleme. Vol. 2. $2^{\text {nd }}$ Edition. Wiesbaden: Springer VS: 1285-1305. 
Kearns, Robin A.; Lewis, Nicolas; Mccreanor, Tim; Witten, Karen 2010: School closures as breaches in the fabric of rural welfare. Community perspectives from New Zealand. In: Milbourne, Paul (Ed.): Welfare reform in rural places. Comparative perspectives. Research in rural sociology and development v. 15. Bingley: Emerald: 219-236.

Kelman, Steven 1987: The Political Foundations of American Statistical Policy. In: Alonso, William; Starr, Paul (Eds.): The politics of numbers. New York: Russell Sage Foundation: 275-302.

Kempkes, Gerhard 2010: Rapid demographic change and the allocation of public education resources: evidence from East Germany. Discussion Paper Series 1: Economic studies. 16/2010. Frankfurt am Main: Deutsche Bundesbank.

Keyfitz, Nathan 1987: The Social and Political Context of Population Forecasting. In: Alonso, William; Starr, Paul (Eds.): The politics of numbers. New York: Russell Sage Foundation: 235-258.

Kramer, Caroline 1997: Schulpolitische Leitbilder und persönliche Einstellungen zu kleinen Grundschulen. Erfahrungen aus Vorarlberg und Baden-Württemberg. In: Sandfuchs, Uwe (Ed.): Kleine Grundschule und jahrgangsübergreifendes Lernen. Schülerrückgang als pädagogische Herausforderung. Bad Heilbrunn: Klinkhardt: 77-93.

Kroll, Alexander 2012: Why public managers use performance information: concepts, theory, and empirical analysis. Dissertation. Potsdam.

Kultusministerium Sachsen-Anhalt 1991: Vorläufige Regelung zur Schulentwicklungsplanung. Erlass des Ministeriums für Bildung, Wissenschaft und Kultur vom 30.1.1991. In: Ministerialblatt für das Land Sachsen-Anhalt 4: 39-40.

Kultusministerium Sachsen-Anhalt 1992a: Klassenbildung und Ermittlung der Lehrersollstunden an Sekundarschulen für das Schuljahr 1992/93. In: Ministerialblatt für das Land Sachsen-Anhalt 2,39: 1105-1108.

Kultusministerium Sachsen-Anhalt 1992b: Rundschreiben des Kultusministeriums an die Landräte und Oberbürgermeister der kreisfreien Städte zur Fortschreibung der vorläufigen Schulentwicklungspläne vom 12.8.1992. In: Schulverwaltungsblatt für das Land Sachsen-Anhalt 1,1: 32.

Kultusministerium Sachsen-Anhalt 1993: Fortschreibung der vorläufigen Schulentwicklungspläne der Landkreise und kreisfreien Städte. In: Schulverwaltungsblatt für das Land Sachsen-Anhalt 2,4: 163-164.

Kultusministerium Sachsen-Anhalt 1999: Verordnung zur Mittelfristigen Schulentwicklungsplanung (MitSEPI-VO). 17.11.1999. In: Gesetz- und Verordnungsblatt für das Land Sachsen-Anhalt 39: 356-359.

Kultusministerium Sachsen-Anhalt 2000: Mittelfristige Schulentwicklungsplanung (MitSEPI-VO). Vorläufige Planungshinweise vom 21.01.2000. Magdeburg: Kultusministerium Sachsen-Anhalt.

Kultusministerium Sachsen-Anhalt 2002: Mindestschülerzahlen zur Bildung von Anfangsklassen. Runderlass des MK vom 27.11.2002. In: Schulverwaltungsblatt für das Land Sachsen-Anhalt 11,14: 287-288.

Kultusministerium Sachsen-Anhalt 2003a: Planungshinweise: Mittelfristige Schulentwicklungsplanung. Magdeburg. Kultusministerium Sachsen-Anhalt [http://www.mkintern.bildung-Isa.de/Bildung/planungshinweise.pdf, 20.09.2014].

Kultusministerium Sachsen-Anhalt 2003b: Verordnung zur Änderung der Mittelfristigen Schulentwicklungsplanung (MitSEPI-VO) vom 5.5.2003. In: Gesetz- und Verordnungsblatt für das Land Sachsen-Anhalt 12,5: 92-95. 
Kultusministerium Sachsen-Anhalt 2008a: Verordnung zur Änderung der Verordnung zur Bildung von Anfangsklassen und zur Aufnahme an allgemein bildenden Schulen. 06.10.2008. In: Gesetz- und Verordnungsblatt für das Land Sachsen-Anhalt 21: 317.

Kultusministerium Sachsen-Anhalt 2008b: Verordnung zur Schulentwicklungsplanung (SEPI-VO). 22.09.2008. In: Gesetz- und Verordnungsblatt für das Land Sachsen-Anhalt 20: 309-313.

Kultusministerium Sachsen-Anhalt 2013: Verordnung zur Schulentwicklungsplanung 2014 (SEPI-VO 2014) vom 15. Mai 2013. Magdeburg: Kultusministerium Sachsen-Anhalt [http://www.mk.bildung-lsa.de/bildung/ve-schulentwicklungsplanung_2013.pdf, 21.09.2016].

Lampland, Martha 2010: False numbers as formalizing practices. In: Social Studies of Science 40,3: 377-405.

Landtag von Sachsen-Anhalt 1993: Antwort der Landesregierung auf die Große Anfrage zu Drs. 112898. Drucksache. 1/3023. Magdeburg: Landtag von Sachsen-Anhalt.

Landtag von Sachsen-Anhalt 2015: Parlamentsdokumentation 1991-2014. Magdeburg [http://padoka.landtag.sachsen-anhalt.de, 21.09.2016].

Larsson Taghizadeh, Jonas 2015: Quality over quantity? Technical information, interest advocacy and school closures in Sweden. In: Interest Groups \& Advocacy 4,2: 101-119.

Lee, Valerie 2006: School Size and the Organization of Secondary Schools. In: Hallinan, Maureen T. (Ed.): Handbook of the Sociology of Education. New York: Springer: 327344.

Lippe, Peter von der 1999: Die politische Rolle der amtlichen Statistik in der ehemaligen DDR. In: Statistisches Bundesamt (Ed.): Amtliche Statistik - ein konstitutives Element des demokratischen Staates: 50 Jahre Bundesrepublik Deutschland. Wiesbaden: 2546.

Lippe, Peter von der 2002: Ein Blick zurück auf die amtliche Statistik der DDR. Schwierigkeiten mit einer Abschlußbilanz. In: Jahrbücher für Nationalökonomie und Statistik 222,5: 609-620.

Luhmann, Niklas 1994: Öffentliche Meinung: Politische Planung. $4^{\text {th }}$ ed. Opladen: Westdeutscher Verlag: 9-34.

Luhmann, Niklas 1996: Die Realität der Massenmedien. $2^{\text {nd }}$ ed. Opladen: Westdeutscher Verlag.

Lundgreen, Peter 2000: Schule im 20. Jahrhundert: institutionelle Differenzierung und expansive Bildungsbeteiligung. In: Benner, Dietrich; Tenorth, Heinz-Elmar (Eds.): Bildungsprozesse und Erziehungsverhältnisse im 20. Jahrhundert. Praktische Entwicklungen und Formen der Reflexion im historischen Kontext. Zeitschrift für Pädagogik: Beiheft 42. Weinheim: Beltz: 140-165.

Lynch, Patrick D.; Tason, Maritzy 1984: Research on Educational Planning: An International Perspective. In: Review of Research in Education 11: 307-367 [doi: 10.3102/0091732X011001307].

Merton, Robert K. 1976: The Sociology of Social Problems. In: Merton, Robert K.; Nisbet, Robert (Eds.): Contemporary Social Problems. $4^{\text {th }}$ ed. New York: Harcourt Brace Jovanovich: 3-43.

Merton, Robert K. 1988: The Matthew Effect in Science, II. Cumulative Advantage and the Symbolism of Intellectual Property. In: Isis 79,4: 606-623.

Messerschmidt, Reinhard 2014: "Garbled demography" or "Demographization of the social"? - A Foucaultian Discourse Analysis of German Demographic Change at the Beginning of the 21st Century. In: Historical Social Research 39,1: 299-335. 
Meusburger, Peter 1998: Bildungsgeographie. Wissen und Ausbildung in der räumlichen Dimension. Heidelberg: Spektrum.

Meyer, John W.; Ramirez, Francisco O. 2012: The World Institutionalization of Education. In: Schriewer, Jürgen (Ed.): Discourse formation in comparative education. Frankfurt am Main: Lang: 111-132.

Meyer, John W.; Ramirez, Francisco O.; Soysal, Yasemin Nuhoglu 1992: World Expansion of Mass Education, 1870-1980. In: Sociology of Education 65,2: 128-149.

Neller, Katja 1999: Lokale Kommunikation. Politikberichterstattung in Tageszeitungen. Wiesbaden: DUV, Deutscher Universitätsverlag.

Ohtake, Fumio; Sano, Shinpei 2010: The Effects of Demographic Change on Public Education in Japan. In: Itō, Takatoshi; Rose, Andrew (Eds.): The economic consequences of demographic change in East Asia. Chicago: University of Chicago Press: 193-219.

Parsons, Talcott 1964: Evolutionary Universals in Society. In: American Sociological Review 29,3: 339-357.

Phipps, Alan G. 2000: A structurationist interpretation of community activism during school closures. In: Environment and Planning A 32,10: 1807-1823.

Post, David; Stambach, Amy 1999: District Consolidation and Rural School Closure: E Pluribus Unum? In: Journal of Research in Rural Education 15,2: 106-117.

Poterba, James M. 1997: Demographic Structure and the Political Economy of Public Education. In: Journal of Policy Analysis and Management 16,1: 48-66.

Prewitt, Kenneth 1987: Public Statistics and Democratic Politics. In: Alonso, William; Starr, Paul (Eds.): The politics of numbers. New York: Russell Sage Foundation: 261274.

Ratts $\emptyset$, Jørn; Sørensen, Rune J. 2010: Grey power and public budgets: Family altruism helps children, but not the elderly. In: European Journal of Political Economy 26,2: 222-234 [doi: 10.1016/j.ejpoleco.2009.11.010].

Reichertz, Jo 2010: Objective Hermeneutics and Hermeneutic Sociology of Knowledge. In: Flick, Uwe; Kardorff, Ernst von; Steinke, Ines (Eds.): A companion to qualitative research. London: Sage: 570-582.

Rose, Nikolas 1991: Governing by Numbers: Figuring out Democracy. In: Accounting, Organizations and Society 16,7: 673-692.

Rösner, Ernst 1999: Schulentwicklungsplanung am Ende des 20. Jahrhunderts. In: Recht der Jugend und des Bildungswesens 47,4: 452-463.

Rösner, Ernst 2004: Ratgeber Schulentwicklungsplanung. Vol. 1: Allgemeinbildendes Schulwesen. Dortmund: IFS-Verlag.

Rottenburg, Richard; Merry, Sally E. 2015: A world of indicators: the making of governmental knowledge through quantification. In: Rottenburg, Richard et al. (Eds.): The World of Indicators. The Making of Governmental Knowledge through Quantification. Cambridge: Cambridge University Press: 1-33.

Rottenburg, Richard; Merry, Sally E.; Park, Sung-Joon; Mugler, Johanna (Eds.) 2015: The World of Indicators. The Making of Governmental Knowledge through Quantification. Cambridge: Cambridge University Press.

Sackmann, Reinhold 2010a: Globalisierung und Kommerzialisierung von Bildungsmärkten: Stand und Perspektiven. In: Barz, Heiner (Ed.): Handbuch Bildungsfinanzierung. Wiesbaden: VS Verlag für Sozialwissenschaften: 367-379. 
Sackmann, Reinhold 2010b: Institutional Responses to Social Change in Comparative Perspective: Germany and Poland. In: Silbereisen, Rainer K.; Chen, Xinyin (Eds.): Social Change and Human Development: Concepts and Results. London: Sage: 167-189.

Sarcinelli, Ulrich 2012: Medien und Demokratie. In: Mörschel, Tobias; Krell, Christian (Eds.): Demokratie in Deutschland. Zustand, Herausforderungen, Perspektiven. Wiesbaden: Springer VS: 271-318.

Schneider, Beate; Möhring, Wiebke; Stürzebecher, Dieter 1997: Lokalzeitungen in Ostdeutschland - Strukturen, publizistische Leistung und Leserschaft. In: Media-Perspektiven 7: 378-390.

Scholz, Manfred 1990: Schulbau in der DDR 1949-1989. Berlin: Sekretariat der Kultusministerkonferenz [https://www.kmk.org/fileadmin/Dateien/veroeffentlichungen beschluesse/1990/1990_01_01-Schulbau-in-der-DDR.pdf, 21.09.2016].

Schwarz, Alexandra; Weishaupt, Horst 2014: Veränderungen in der sozialen und ethnischen Zusammensetzung der Schülerschaft aus demografischer Perspektive. In: Maaz, Kai; Baumert, Jürgen; Neumann, Marko (Eds.): Herkunft und Bildungserfolg von der frühen Kindheit bis ins Erwachsenenalter. Forschungsstand und Interventionsmöglichkeiten aus interdisziplinärer Perspektive. Zeitschrift für Erziehungswissenschaft: Sonderheft 24. Dordrecht: Springer: 9-35.

Seibel, Wolfgang 1993: Zur Situation der öffentlichen Verwaltung in den neuen Bundesländern. In: Seibel, Wolfgang; Benz, Arthur; Mäding, Heinrich (Eds.): Verwaltungsreform und Verwaltungspolitik im Prozess der deutschen Einigung. Baden-Baden: Nomos: 477-498.

Soroka, Stuart; WIezien, Christopher 2015: On the Sources of Public Responsiveness to Policy [http://www.degreesofdemocracy.net/SourcesResponsiveness\%28SorokaWle zienAPSA2015\%29.pdf, 15.02.2016].

Starr, Paul 1987: The Sociology of Official Statistics. In: Alonso, William; Starr, Paul (Eds.): The politics of numbers. New York: Russell Sage Foundation: 7-57.

Statistische Ämter des Bundes und der Länder 2011: Bevölkerungs- und Haushaltsentwicklung im Bund und in den Ländern. Demographischer Wandel in Deutschland 1. Wiesbaden: Statistisches Bundesamt.

Statistische Ämter des Bundes und der Länder 2015: Regionaldatenbank Deutschland. Düsseldorf: Statistische Ämter des Bundes und der Länder [https://www.regionalstatistik.de/genesis/online/logon, 15.02.2016].

Statistisches Bundesamt 1975-2013: Bildung und Kultur. Allgemeinbildende Schulen. Fachserie 11 Reihe 1. Wiesbaden: Statistisches Bundesamt.

Statistisches Landesamt Sachsen-Anhalt 1991-2014: Anschriftenverzeichnis - Allgemeinbildende Schulen. Halle (Saale): Statistisches Landesamt Sachsen-Anhalt.

Statistisches Landesamt Sachsen-Anhalt 2010: Bevölkerung nach Alter und Geschlecht. Sonderauswertung für die Jahre 1991-2009. Gebietsstand 2009. Halle (Saale).

Statistisches Landesamt Sachsen-Anhalt 2016: Allgemeinbildende Schulen insgesamt nach Kreisen 1970-1990. Archivdaten. Halle (Saale).

Stinchcombe, Jean 1984: Response to declining enrollment. School-closing in suburbia. Lanham: University Press of America.

Tenorth, Heinz-Elmar 2008: Das Gymnasium - Leitinstitution des deutschen Bildungswesens. In: Engagement 3: 252-263.

Thévenot, Laurent 2009: Postscript to the Special Issue. Governing Life by Standards: A View from Engagements. In: Social Studies of Science 39,5: 793-813 [doi: 10.1177/0306312709338767]. 
Thomaß, Barbara 2015: Massenmedien. In: Kollmorgen, Raj; Merkel, Wolfgang; Wagener, Hans-Jürgen (Eds.): Handbuch Transformationsforschung. Wiesbaden: Springer VS: 617-623.

Uba, Katrin 2015: The power of ad hoc mobilisation: postponing school closures in Sweden. 110th ASA Annual Conference. Chicago, III: American Sociological Association.

Ullrich, Heiner 2014: Exzellenz und Elitenbildung in Gymnasien. Traditionen und Innovationen. In: Krüger, Heinz-Hermann; Helsper, Werner (Eds.): Elite und Exzellenz im Bildungssystem. Nationale und internationale Perspektiven. Zeitschrift für Erziehungswissenschaft: Sonderheft 19. Wiesbaden: Springer VS: 181-201.

Uppendahl, Herbert 1981: Repräsentation und Responsivität. Bausteine einer Theorie responsiver Demokratie. In: Zeitschrift für Parlamentsfragen 12,1: 123-134.

Weishaupt, Horst 2006: Veränderungen im elementaren und sekundären Bildungsbereich durch demographischen Wandel. In: Statistisches Bundesamt (Ed.): Demographischer Wandel - Auswirkungen auf das Bildungssystem. Beiträge zum wissenschaftlichen Kolloquium am 18. und 19. November 2004 in Wiesbaden. Statistik und Wissenschaft 6. Wiesbaden: Statistisches Bundesamt: 26-44.

Winkler, Markus 2011: Schulentwicklungsplanung zwischen kommunaler Selbstverwaltung und staatlicher Schulverantwortung. In: Die öffentliche Verwaltung 64,17: 686694.

Wolter, Stefan C. 2009: Der intergenerationelle Konflikt bei Bildungsausgaben. In: Zeitschrift für Pädagogik 55: 4-16.

Zymek, Bernd; Wendt, Sabine; Hegemann, Moritz; Ragutt, Frank 2011: Regional Governance und kommunale Schulentwicklungspolitik im Prozess des Rück- und Umbaus regionaler Schulangebotsstrukturen. In: Zeitschrift für Pädagogik 57,4: 497-513.

Dr. Walter Bartl (ه). Martin-Luther-University Halle-Wittenberg, Institute of Sociology. Halle (Saale), Germany. E-mail: walter.bartl@soziologie.uni-halle.de URL: http://soziologie.uni-halle.de/professuren/sozialstruktur/mitarbeiter/bartl/

Prof. Dr. Reinhold Sackmann. Martin-Luther-University Halle-Wittenberg, Institute of Sociology. Halle (Saale), Germany.E-mail: reinhold.sackmann@soziologie.uni-halle.de URL: http://soziologie.uni-halle.de/professuren/sozialstruktur/sackmann/ 


\section{Comparative Population Studies}

WWW.comparativepopulationstudies.de

ISSN: 1869-8980 (Print) - 1869-8999 (Internet)

Published by

Prof. Dr. Norbert F. Schneider

Federal Institute for Population Research

D-65180 Wiesbaden / Germany

\section{(cc) BY-SA}

2016

\section{Managing Editor}

Frank Swiaczny

\section{Assistant Managing Editor}

Katrin Schiefer

\section{Copy Editor}

(Selected Articles in German)

Dr. Evelyn Grünheid

\section{Layout}

Beatriz Feiler-Fuchs

E-mail:cpos@bib.bund.de

\section{Scientific Advisory Board}

Paul Gans (Mannheim)

Karsten Hank (Köln)

Johannes Huinink (Bremen)

Michaela Kreyenfeld (Rostock)

Marc Luy (Wien)

Notburga Ott (Bochum)

Peter Preisendörfer (Mainz)

Nikola Sander (Groningen)

Zsolt Spéder (Budapest)

\section{Board of Reviewers}

Martin Abraham (Erlangen)

Laura Bernardi (Lausanne)

Hansjörg Bucher (Bonn)

Claudia Diehl (Konstanz)

Andreas Diekmann (Zürich)

Gabriele Doblhammer-Reiter (Rostock)

Jürgen Dorbritz (Wiesbaden)

Anette Eva Fasang (Berlin)

E.-Jürgen Flöthmann (Bielefeld)

Alexia Fürnkranz-Prskawetz (Wien)

Beat Fux (Salzburg)

Joshua Goldstein (Berkeley)

Sonja Haug (Regensburg)

Hill Kulu (Liverpool)

Aart C. Liefbroer (Den Haag)

Kurt Lüscher (Konstanz)

Emma Lundholm (Umeå)

Nadja Milewski (Rostock)

Dimiter Philipov (Wien)

Roland Rau (Rostock)

Tomáš Sobotka (Wien) Jeroen Spijker (Barcelona)

Olivier Thévenon (Paris)

Helga de Valk (Brussel)

Heike Trappe (Rostock)

Michael Wagner (Köln) 